\title{
Different speakers, different grammars: Productivity and representation of Xhosa labial palatalization
}

\author{
William G. Bennett ${ }^{a} \&$ Aaron Braver ${ }^{b^{*}}$ \\ aRhodes University - w.bennett@ru.ac.za \\ bTexas Tech University - aaron.braver@ttu.edu
}

\begin{abstract}
While cross-linguistic studies suggest that palatalization is preferentially triggered by high and front vocoids, and that it targets coronals or dorsals, Xhosa has a process of palatalization that is triggered by [w], and that targets only bilabials. This paper presents a wug test experiment, showing that some Xhosa speakers do systematically generalize this phenomenon to nonce words. This suggests that for those speakers, labial palatalization is indeed learned as part of their phonological grammar. Additionally, our findings show that some other speakers systematically do not apply palatalization in nonce words, suggesting that they have learned it as a pattern in the lexicon, and not as part of phonology. Drawing on evidence from a separate wug test experiment, we show that the inter-speaker variation in our results cannot be explained away as a task effect. As such, our results show that different speakers can have fundamentally different grammatical representations of the same sound pattern. Though Xhosa's labial palatalization pattern is phonetically unnatural, that does not indicate that it is necessarily outside the domain of phonology proper.
\end{abstract}

Keywords: Xhosa; morphophonology; experimental phonology; variation; dissimilation; palatalization; productivity

\section{Introduction}

Previous cross-linguistic studies of palatalization identify numerous clear and robust tendencies, some of which verge on being universals (Bateman 2007, 2011; Kochetov 2011). One well-known tendency is that palatalization is most commonly triggered by high and front vocoids - a trend so clear that Bhat's (1978) pioneering survey takes it as a sufficient characteristic for defining the term 'palatalization'. Another clear tendency is that palatalizing alternations preferentially target coronals or dorsals, and not labials. Thus, stereotypical palatalization processes are alternations such as $\mathrm{ti} \rightarrow \mathrm{tii}, \mathrm{ti} \rightarrow \mathrm{t} f \mathrm{i}$, or $\mathrm{ki} \rightarrow \mathrm{t} \mathrm{ji}-$ alveolars and/or velars becoming (alveo)-palatal before a high, front, vowel.

Deviations from this norm do exist, of course. Other front vowels besides [i] can trigger palatalization. Palatalization before high back vocoids is actually attested - but seemingly never without similar palatalization induced by front vowels. By way of example, consider Tohono O'odham, which is reported

\footnotetext{
* Acknowledgments are due to many people for suggestions, comments, and helpful discussion at various points in the genesis of this work. We thank Martin Krämer, Olga Urek, Seunghun Lee, Andrew Van der Spuy, Lionel Posthumus, Jochen Zeller, Andries Coetzee, John Ohala, Richard Bailey, Eva-Marie Bloom-Ström, Mark de Vos, and audiences in Tromsø, San Diego, and Potchefstroom. For help preparing stimuli and collecting data, we thank Msindisi Sam, Kelly Goldstuck, Danica Kreusch, Olona Tywabi. Supporting funding was received from the Rhodes University Research Committee, and the South African National Research Foundation. Authors' names are in alphabetical order. An earlier working paper based on the same experiment data was published in Nordlyd in 2018.
} 
to have palatalization triggered by non-high [e] and non-front $[\mathrm{u}]$. But, the same palatalization is also triggered by [i] in Tohono O'odham. This case mirrors the apparent typological generalization: high vowels and front vowels can each trigger palatalization - but both of these imply palatalization triggered by high front vowels. Similar implications are reported for the consonants that undergo palatalization. Bateman $(2007,2010)$ records palatalization of labials in Moldavian; but, Moldavian also palatalizes non-labials in precisely the same contexts. The apparent generalization: labials are the worst undergoers of palatalization, and palatalize only when coronals and/or dorsals also do so.

In view of these strong cross-linguistic generalizations, palatalization in Southern Bantu languages stands out as rather curious. The generalization in question, discussed extensively in previous grammatical and phonological descriptions, is that labials palatalize before [w] (1). Examples are given below from Xhosa; cognates of the pattern are also found in Zulu, Ndebele, Swati, Tsonga, Tswana, Sotho, and Venda. ${ }^{1}$ The forms in (2) show that passives are normally formed with the suffixal verb extension $/-\mathrm{w}-/ .^{2}$ When a root ends in a labial, that labial turns into a palatal when the passive suffix is added (3). This is clearly palatalization, in that the alternation changes non-palatals into primary palatals, despite departing from the stereotypical $\mathrm{ki} \rightarrow \mathrm{t} \int \mathrm{i}$ example noted above. ${ }^{3}$

(1) Xhosa labial palatalization

/...B.../ $+/-\mathrm{w} / \rightarrow \ldots \mathrm{J} . . . \mathrm{-w}$

labial + labial $\rightarrow$ palatal + labial

(2) Xhosa passive formation with /-w-/

a. úkù-fún ${ }^{\mathrm{n}}-\mathrm{à}$

INF-study-FV

'to study'

b. úkù-fün d-w-à

INF-study-PASS-FV

'to be studied'

(3) Palatalization of labials in passives

a. uku-tâm $\hat{\mathbf{m}}^{\mathbf{m}}$-à

INF-wash-FV

'to wash, cleanse'

b. úkù-łàn $\widehat{\mathbf{d}}$-w-à

INF-wash-PASS-FV

$\left(*-a^{\mathrm{m}} \mathbf{b w a} ;{ }^{\mathrm{m}} \mathrm{b} \rightarrow{ }^{\mathrm{n}} \widehat{\mathrm{d}}\right.$ palatalization $)$

'to be washed, cleansed'

The palatalization seen in passive forms like (3b) only affects labials; coronals and velars are not palatalized by this /-w-/. Additionally, while the passive /-w-/ causes palatalization, high and front vocoids like /i/ and

\footnotetext{
${ }^{1}$ For further details and/or analyses of the pattern, see Doke $(1923,1954)$, Khumalo $(1987,1988)$ - Zulu; Sibanda (2004) - Ndebele; Chen \& Malambe (1998); Malambe (2006) - Siswati; Louw (1976), Baumbach (1987), Lee \& Burheni (2014) - Xitsonga; Cole (1955), Ohala (1978), Herbert (1977, 1990), Kotzé \& Zerbian (2008) - Sotho and Tswana; Louw (1976), Nemakhavhani (2002), Malambe (2006) - Tshivenda.

${ }^{2}$ The tonology of Xhosa is highly complex and richly varied across dialects, and is also outside the scope of this paper. Tone is not marked in the orthography, and as such is not always indicated in previous sources. In this paper, we generally mark tones in examples following the Greater Dictionary of isiXhosa (Tshabe et al. 2006; GDX), except where examples from other sources explicitly indicate a different tone pattern. Except where noted otherwise, vowels with no marked tone are ones that have systematically variable tone depending on the dialect and/or speaker, or are otherwise uncertain.

${ }^{3}$ The Leipzig Glossing Rules (https://www.eva.mpg.de/lingua/resources/glossing-rules.php) are followed for glossing language examples. These are supplemented by abbreviations listed in the Abbreviations section at the end.
} 
/j/ do not. This is shown below in (4). The /i/ in the causative suffix /-is-/ does not cause palatalization in (4a), even though the same stem does exhibit palatalization when passivized (4b). Likewise, even though /6/ can palatalize, it does not do so before $/ \mathrm{j} /(4 \mathrm{c})$, even if there is also an /i/ accompanying it (4d). The failure of palatalization in these examples cannot plausibly be attributed to the intervening [a]: palatalization routinely ignores multiple intervening segments, both in monomorphemic roots (4e), and in suffixes (4b). Other segments that are not bilabials are not palatalized (4f). (This suggests that the pattern may be characterized as accurately as 'dissimilation' as as 'palatalization'; we will continue to use the latter label, as it is more common in previous work on this data.)

(4) [i] and [j] do not trigger palatalization in Xhosa
a. uku-kx'ób-ìs-à
INF-peep.over-CAUS-FV
'to peep over something'
b. uku-kx'óc'-ì̀- $\underline{w}-a ̀$
INF-peep-CAUS-PASS-FV
'to be made to peep over something'
c. úkù- $\widehat{k x}$ 'ábáj-à
INF-boast-FV
'to boast, brag'
d. úkù-kx'ábájìj-à
INF-ridicule-FV
'to ridicule, make a fool of'
e. úkù-sec'én ${ }^{\mathrm{n}} \mathrm{z}-\underline{\mathrm{w}}$-à
INF-work-PASS-FV
'to be worked'
f. úkù-!wakán-ìs-w-wà
INF-break.up-CAUS-PASS-FV
'to be broken apart'
(*-אx'oc'isa; no palatalization)
(*-אx' obiswa; /6/ palatalized before /w/)
(*-אx'ac'aja; no palatalization)
(*-אx'ac'ajija; no palatalization)
(*-sebe ${ }^{\mathrm{n}}$ zwa; nonlocal palatalization)

The points here are (i) that the palatalization in this case is triggered by /-w-/, and (ii) that it affects labials to the exclusion of coronals and dorsals - even when coronals and dorsals intervene between the $/ \mathrm{w} /$ and the labial undergoing the change. If the universals of palatalization evident from previous typological surveys are reliable, then this kind of palatalization process should not exist as such. We are therefore driven to wonder: is this actually a real phonological process? Or is the fundamental divergence from other cases of palatalization perhaps due to this pattern operating outside the scope of normal phonology?

Potential non-phonological characterizations of the data are not hard to come by. For instance, it could be that palatalization is not a consequence of the segment $/ \mathrm{w} /$, but rather is a characteristic of passive verb stems. Along those lines, passive forms with palatals might be stored fully-formed in the lexicon. The synchronic relation between these stems and their active counterparts could be one of suppletion, on par with English goose geese: two surface forms that are superficially similar, but are fundamentally related by morphology and etymology - and not phonology. In that scenario, passive forms with palatals would not be derived by any synchronic palatalization process. Instead, the palatalization seen in Xhosa and other Southern Bantu languages could be a historical relic of past sound changes, as has been proposed in some previous work (see Ohala 1978; Herbert 1977, 1990, etc.). The line of analysis generally taken in these accounts is that the passive suffix was historically ${ }^{-1 w}{ }^{4}$; the palatalization is not a synchronic

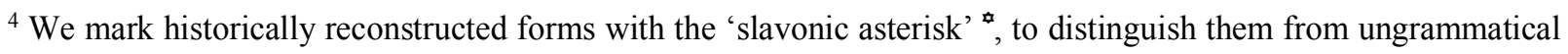
forms marked with *. We note also that this reconstruction is not without its quibbles: on the one hand, it makes the
} 
change triggered by $[\mathrm{w}]$, but rather a historical one triggered by a high front vocoid $\mathrm{i}$ that was subsequently lost. On this view, the reason the Xhosa palatalization pattern is typologically anomalous is that it is really not a product of synchronic phonology per se. Rather, it is interpreted as the product of a more typical palatalization pattern, obscured by subsequent diachronic change - and the synchronic implementation of the alternation would lie in the morphology or the lexicon.

The first goal of this paper is to shed new light on the status of bilabial palatalization in Xhosa (and, by extension, other Nguni languages with the same pattern), using an experiment of the classic wug test type (Berko 1958) to distinguish between these two hypotheses. If the labial palatalization alternation is part of regular phonology, it ought to apply regularly in nonce words. If it is due to something outside phonology, then palatalized forms are presumably memorized rather than computed: palatalization should not generalize to novel words, because they have no existing lexical entries (palatalized or otherwise).

Our results show that some speakers palatalize real and nonce words systematically, while others fail to palatalize nonce words. We claim that palatalization is indeed part of phonology proper for some speakers. Therefore, the typologically anomalous character of this palatalization cannot be attributed to it being non-phonological. However, other speakers, namely those who do not palatalize in nonce words, behave in a fashion consistent with the hypothesis that palatalization is outside of the phonology portion of the grammar. Thus, the predictions of both hypotheses are borne out in our data, but for different speakers.

Showcasing this finding about inter-speaker variation is the second goal of this paper. The differences between our experiment participants connect to a point of broad significance: members of the same speech community can learn different phonological grammars. Some speakers have a grammar where palatalization is part of the regular phonology, and others do not - even though they were presumably exposed to more or less the same input. This finding has significant methodological ramifications, as noted in some previous work (see, for example, Zsiga et al. 2006 and de Lacy 2009): pooling data across speakers has the potential to obscure the fact that different speakers may have internalized very different phonological systems.

The paper is organized as follows. Section 2 presents further details and background both about the Xhosa language, and about the labial palatalization phenomenon in question. Section 3 reports on a production experiment to assess productivity of the pattern; Section 4 presents the findings of this experiment. Section 5 further discusses the implications of our experimental results, including our interpretation of the results, as well as some consideration of an alternative interpretation based on analogy. Section 6 discusses additional directions this research points at, while Section 7 summarizes our conclusions: that different speakers have different grammars - some with phonological palatalization, and some without.

\section{Background}

Xhosa (also known as isiXhosa [isí-\|hòsà] ${ }^{5}$ ) is a Southern Bantu language of the Nguni family, spoken primarily in the Eastern Cape of South Africa, with significant numbers of speakers in most urban centers throughout the region.

The non-click consonant inventory of standard Xhosa is given in Table 1 (adapted from Tshabe et al. 2006). All stops and affricates have a three-way laryngeal contrast (labials also contrast with implosive [6]). This is traditionally described as a contrast between aspirated, ejective, and voiced sets, but the phonetic facts on the ground are somewhat more complex than this implies. Voiceless unaspirated stops are not

passive extension the same -VC- shape as other productive extensions (causative -is-, applicative -el-, middle -ek-). On the other hand, the causative extension is reconstructed with the same high front vocoid, and never induces palatalization.

${ }^{5}$ isiXhosa is the Xhosa name for the Xhosa language; the prefix isi- marks nouns of class 7, which includes all language names derived from ethnonyms. This distinguishes isiXhosa from other words with the same stem, like amaXhosa 'the Xhosa people/race', and umXhosa 'a Xhosa person'. 
systematically ejective, except after homorganic nasals; voiced stops may not be fully voiced (see Jessen \& Roux 2002 for further details). $\mathrm{Cw}$ and $\mathrm{NC}$ sequences occur, and are analyzed as single segments by some sources, but are not included in this table; we transcribe $\mathrm{NC}$ sequences as prenasal $\left({ }^{\mathrm{N}} \mathrm{C}\right)$ elsewhere. ${ }^{6}$

Table 1: Xhosa non-click consonant inventory (based on Tshabe et al. 2006)

\begin{tabular}{|c|c|c|c|c|c|c|c|}
\hline & Bilabial & $\begin{array}{l}\text { Labio- } \\
\text { dental }\end{array}$ & Alveolar & $\begin{array}{l}\text { Post- } \\
\text { alveolar }\end{array}$ & Palatal & Velar & Glottal \\
\hline Stop & $p^{\prime} p^{h} b 6$ & & $t^{\prime} t^{h} d$ & & $c^{\prime} c^{h} J$ & $\mathrm{k}^{\prime} \mathrm{k}^{\mathrm{h}} \mathrm{g}$ & \\
\hline Fricative & & fv & $\begin{array}{l}\text { s z } \\
13\end{array}$ & $\int$ & & $\mathrm{x} \mathrm{y}$ & h h \\
\hline Affricate & & & $\frac{\mathrm{ts}^{\prime}}{\mathrm{tt}_{\mathrm{tg}}} \overline{\mathrm{dl}}^{\mathrm{h}} \overline{\mathrm{dz}}$ & $\frac{\mathrm{t} \int^{2}}{\mathrm{~d} 3}$ & & $\widehat{\mathrm{kX}}$, & \\
\hline Nasal & $\mathrm{m} \mathrm{m} \mathrm{m}^{\mathrm{f}}$ & & $\mathrm{n} \underline{n ! n}^{\mathrm{f}}$ & & $\mathrm{n} \mathrm{n}^{\mathrm{h}}$ & y & \\
\hline Approximant & $\mathrm{w} \mathrm{w}^{\mathrm{f}}$ & & $\operatorname{lr}$ & & $\mathrm{j} \mathrm{j}{ }^{\mathrm{fi}}$ & & \\
\hline
\end{tabular}

(Segments in grey are uncommon, marginal, and/or have very restricted distributions.)

\subsection{Labial palatalization up close}

The labial palatalization alternation is a constellation of changes which are listed in Table 2. The column on the left gives the phonetic values of the segments, following traditional descriptions (McLaren 1942; Doke 1954, etc.); the second column gives their usual representations in standard Xhosa orthography. The final two columns give examples of verb stems with the relevant segment in non-initial position, and corresponding passive forms (examples are given in orthography, as they are listed in Tshabe et al. 2006; underlines mark each locus of the alternation).

Table 2: Labial palatalization mappings

\begin{tabular}{|c|c|c|c|}
\hline IPA & Orthog. & Examples (stem $\sim$ passive) & Gloss \\
\hline$\left[\mathrm{p}^{\prime}\right] \rightarrow\left[\mathrm{t} \jmath^{\prime}\right]$ & $p \rightarrow t s h$ & -kopakopa $\sim-k o \underline{t s h} w a k o \underline{t s h} w a$ & 'turn out/over' \\
\hline$\left[\mathrm{p}^{\mathrm{h}}\right] \rightarrow\left[\mathrm{t} \int^{\mathrm{h}}\right]$ & $p h \rightarrow t s h$ & -xhapha $\sim$-xhatshwa & 'lap up' \\
\hline$[6] \rightarrow\left[c^{\prime}\right]$ & $b \rightarrow t y$ & $-q h o \underline{b} o s h a \sim-q$ hotyoshwa & $\begin{array}{l}\text { 'have one's hands } \\
\text { tied' }\end{array}$ \\
\hline$[\mathrm{b}] \rightarrow[\widehat{\mathrm{d}} 3]$ & $b h \rightarrow j$ & $-k o l o \underline{b h a} \sim-k o l o j w a$ & 'scrub' \\
\hline$[\mathrm{m}] \rightarrow[\mathrm{n}]$ & $m \rightarrow n y$ & $-q h u \overline{m a} \sim-q h u n \underline{z} w a$ & 'emit smoke' \\
\hline$\left[{ }^{\mathrm{m}} \mathrm{b}\right] \rightarrow\left[{ }^{\mathrm{n}} \mathrm{d}\right]$ & $m b \rightarrow n j$ & -hambela -hanjelwa & 'visit' \\
\hline$\left[{ }^{\mathrm{m}} \mathrm{p},\right] \rightarrow\left[{ }^{\mathrm{n}} \mathrm{t} \rho^{\prime}\right]$ & $m p \rightarrow n t s h$ & -shumpula $\sim-$ shuntshulwa & 'pinch/pluck' \\
\hline
\end{tabular}

The essential generalization is that labials change to their nearest palatal/post-alveolar counterpart. In some cases, there are other disparities besides a place change (e.g. affrication in $\mathrm{p}^{\mathrm{h}} \rightarrow \mathrm{t} \int^{\mathrm{h}}$, and $\mathrm{b} \rightarrow \mathrm{d} 3$, rather than changing to true palatal $\mathrm{f}$ ). These are also a point of some variation across Nguni languages (in Zulu, for instance, $\mathrm{p}^{\mathrm{h}}$ palatalizes to $\int$ rather than $\mathrm{t}^{\mathrm{h}}$ ). ${ }^{7}$ We must leave a full understanding of such details as a matter for future work to investigate more thoroughly.

\footnotetext{
${ }^{6}$ There are 15 click consonants, not listed in the table for reasons of space. These consist of dental [l], lateral [\|], and alveolar [!] click types, each of which permits a 5-way contrast between voiceless, voiced, nasal, breathy nasal, and aspirated. See Tshabe et al. (2006) for further details about the relationship between orthography and IPA.

${ }^{7}$ Verbs with non-initial /w/ are not especially common, but based on the limited data available to us, $/ \mathrm{w} /$ does not appear to palatalize ([-łáwùlà] 'pay for', passive [-łàwùlwà]; Tshabe et al. 2006). Labiodentals are similarly unaffected: [-tófà] 'vaccinate', passive [-tófwà].
} 
Palatalization is also evident in several other morpho-phonological contexts, which we do not analyze in this paper. Synchronically, the same set of alternations in Table 2 may be triggered by the diminutive suffix /-ana/, and the locative suffix /-ini/ (5) (examples from Louw $1976^{8}$ ). They are also evident as diachronic changes (6) - most obviously with vowel-initial stems of class 14 , which is normally marked by the prefix /ubu- $/$.

\begin{tabular}{|c|c|}
\hline Palatalization i & atives and dimi \\
\hline Noun & Locative \\
\hline$i^{\mathrm{m}}$ bubo & $\mathrm{e}^{\mathrm{m}}$ búd 3w-eni \\
\hline uḿlomo & emlój-eni \\
\hline úzipho & elúzít ${ }^{\mathrm{h}}{ }^{\mathrm{n}}$-eni \\
\hline amát ${ }^{\mathrm{h}} \mathbf{u}^{\mathbf{m}} \mathbf{b u}$ & emat ${ }^{h} u^{n} \mathbf{d} z$-ini \\
\hline
\end{tabular}

$\begin{array}{ll}\text { Diminutive } & \text { Gloss (of noun) } \\ \text { imbúdzw-ana } & \text { 'destruction' } \\ \text { umlón-ana } & \text { 'mouth' } \\ \text { uzít's'-ana } & \text { 'nail' } \\ \text { amathún }{ }^{\text {ndz-ana }} & \text { 'entrails' }\end{array}$

(6) Diachronic palatalization

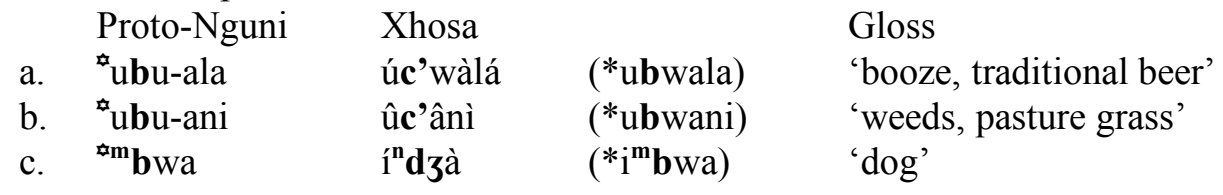

A rather intuitive conception of the examples above (found, e.g. in Khumalo 1987; Poulos \& Msimang 1998 ) is that hiatus resolution creates a glide [w] out of an underlying round vowel, and this [w] is then responsible for palatalization of the preceding labial by the same mechanism as in passives - whatever that might be. Though intuitive, this analysis oversimplifies the pattern in two important ways, as illustrated by the data in (7) from Louw (1976), and as noted previously by Louw, among others. First, considerable variation is reported for locatives and diminutives: some nouns never palatalize (7a-b), other nouns palatalize with one suffix but not the other $(7 \mathrm{c})$, and sometimes both variants may be allowed in one form, or the other, or both $(7 \mathrm{~d}, \mathrm{e}, \mathrm{f})$. Second, palatalization in diminutives and locatives is not phonetically transparent or consistent. Locatives and diminutives exhibiting palatalization usually do not retain any $[w]$ on the surface $(5 b-d, 6 b-c)$. At the same time, palatalization in the locative and diminutive is not exclusive to those nouns that end in round vowels from which a [w] could conceivably be derived. Palatalization can also occur in nouns where there is no basis to expect even a derived [w] (7d-e). Variation and optionality do not obviously correlate with the presence of a stem-final round vowel. ${ }^{9}$

(7) Inconsistent palatalization in locatives and diminutives (Louw 1976)

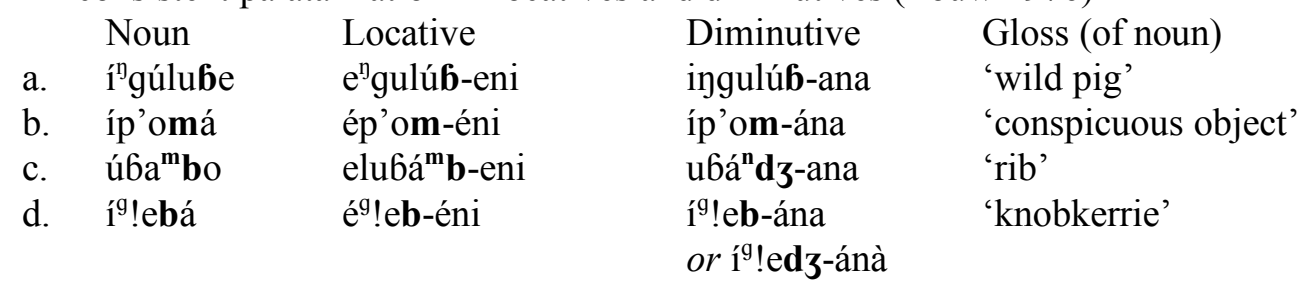

${ }^{8}$ Tone marking in these examples follows Louw, which appears to be phonemic indication of high tones only. Tshabe et al. (2006) give different tone patterns in some items. Variation in the first vowel of the locative suffix is due to coalescence with the stem-final vowel.

${ }^{9}$ It is also worth noting that palatalization is extremely common in diminutives cross-linguistically, and might be regarded as expressive of smallness in a sound-symbolic way (see Kochetov \& Alderete 2011 and sources therein). Beckman (1993: 2) explicitly notes this possibility in connection with Zulu. In Zulu (but not Xhosa), diminutives also exhibit sporadic palatalization of coronals, not just labials (Doke 1923; Khumalo 1987; Herbert 1990, etc.). Zulu data collected by the authors also shows variation, including diminutives ending in [-jana], with an overt palatal [j], and the suffix [-jana]. These differences suggest that the motivation and mechanism of palatalization in diminutives are plausibly not the same as palatalization before the passive /-w-/ in Zulu - and perhaps in Xhosa as well. 


\begin{tabular}{|c|c|c|c|}
\hline e. úmbombó & emb́6omb-éni & uḿbondz-ána & 'arch of nose' \\
\hline íll $\mathbf{o b a}$ & $\begin{array}{l}\text { éllhób-eni } \\
\text { or éllhóc'-eni }\end{array}$ & $\begin{array}{l}\text { íl'óób-ana } \\
\text { or íllhóc'-ana }\end{array}$ & 'loot' \\
\hline
\end{tabular}

Several key sets of facts suggest a distinction between palatalization in passives, and palatalization in diminutives and locatives. First, the latter show variation and inconsistency as noted above; comparable variation is not reported for passives. Some sources imply variation in the behaviour of stem-medial labials (e.g. McLaren 1942: 102) ${ }^{10}$, but otherwise descriptions from different sources are extremely consistent: stem-final labials obligatorily palatalize. Second, long-distance palatalization is found in passives (4b, e), but is not reported in diminutives or locatives, or as diachronic changes (Doke 1954; Poulos \& Msimang 1998, inter alia). Third, passives are not opaque: all passive verbs exhibiting palatalization have a surface $[w]$. Finally, there may be an asymmetry in the palatalization behaviour of loanwords in passives versus locatives and diminutives. Louw (1976: 262) notes that the verb [úku- ${ }^{\mathrm{m}} \mathrm{pó}^{\mathrm{m}} \mathrm{p}$-a] 'pump', borrowed from Afrikaans pomp, palatalizes when passivized ([úku_p' '́t t'wa] 'be pumped'); but he notes that nouns with $/ \mathrm{p} /$ do not palatalize in locatives or diminutives (Afr. pop 'doll' > [ú-popi], loc. [epópini]; Afr. pap 'mush (of grain)' > [í-papa], dim. [ipápana]) (see also Herbert 1990: 77). The Greater Dictionary of isiXhosa (Tshabe et al. 2006) does not include diminutive or locative forms in most entries, but borrowed verbs with listed palatalized passive forms are found in abundance (e.g. copy > [úkùkópà], passive [úkùkót]wà]; $r o b$ $>$ [ukúròbà], passive [ukúrodzwa]).

Taken together, these differences suggest that palatalization in passives seems to exhibit the regularity expected of a purely phonological pattern, while palatalization in diminutives and in locatives exhibit considerably more variation, and less productivity. If palatalization in any of these contexts is a potential product of real and regular phonology, it would be palatalization in passives - so this case is what we focus on in this paper.

\subsection{Is palatalization phonological, or historo-morpho-lexical?}

Some previous work on labial palatalization treats the alternations as a phonological pattern of a completely normal sort; we call this the phonological hypothesis. For example, Doke (1954: 39) attributes palatalization to 'incompatibility of bilabial consonants with the semi-vowel [w]'. This characterization can be taken to imply a phonotactic prohibition against clusters of the form $\mathrm{B}+\mathrm{w}$, and/or the repair of such sequences by a dissimilatory process that turns the labial into a palatal. Some subsequent work has also taken this dissimilation interpretation of the pattern, and analyses based on this idea have been proposed based on various theories of dissimilation (e.g. Gorecka 1989; Beckman 1993; Bennett 2015). Empirically, the dissimilatory interpretation is also supported by the near-total absence of Bw sequences generally (Podile 2002: 118), suggesting that the alternation coincides with an independently-evident co-occurrence restriction. ${ }^{11}$

${ }^{10}$ The Greater Dictionary of isiXhosa (Tshabe et al. 2006) includes some passive forms where non-final labials palatalize, and some with non-palatalized medial labials, and some stems with both options (e.g. uku-!hagámfèlà 'fasten, tie together', passive forms [uku-!hagámfèlwà] and [uku-!hagánífèlwà]). Since many entries do not include any passive form, we interpret these as non-exhaustive lists.

11 The avoidance of Bw clusters in Xhosa also involves other morpho-phonological patterns besides palatalization. For example, hiatus resolution often turns $\mathrm{Cu}$ sequences into $\mathrm{Cw}$ before another vowel. Thus, the class 11 prefix is normally /lu-/, but the /u/ surfaces as [w] in possessives like /lu- + -ak ${ }^{\mathrm{h}} \mathrm{O} / \rightarrow$ [lwák $\left.{ }^{\mathrm{h}} \mathrm{ò}\right]$ 'your (sg.) (cl.11)', and /lu- + - eth $^{\mathrm{h}} \mathrm{u} \rightarrow$ [lwèt $\left.{ }^{\mathrm{h}} \mathrm{u}\right]$ 'our (cl.11)', where it precedes a vowel-initial stem. The same $/ \mathrm{u} / \rightarrow[\mathrm{w}]$ shift is found with other noun classes as well, but does not happen for class $14 / 6 \mathrm{~b}-/$, where it would yield [6w]: /6u- + -ak $\mathrm{o} / \rightarrow$ [6ák $\mathrm{o}]$ 'your (sg.) (cl.14)' (not *6wak ${ }^{\mathrm{h}} \mathrm{o}$ ). Similarly, gliding also fails to obtain in some other morphological contexts after labials (e.g. the root /-ak $\mathrm{h}_{-} /$'build' triggers gliding of a preceding /u/ in its infinitival form [úkwâkhà], but there is no glide in [úmâk'ì] 'builder', despite the class 1 prefix being historically/umu-/). Surface [mw] clusters can be found in native 
Though we are inclined to analyze the labial palatalization in Xhosa as a kind of dissimilation (following Bennett 2015), this is not strictly crucial to the question at hand. Some other treatments analyze palatalization as something other than dissimilation, but take a similarly phonological interpretation of the basic facts; we regard these as different sub-types of the essential phonological hypothesis. For instance, rather than treating the process as dissimilation, we could posit a floating [+palatal] feature in the morphemes associated with palatalization, with this floating feature triggering palatalization in a more straightforward fashion by docking onto a preceding segment (for examples of this line of analysis see Chen \& Malambe 1998; Naidoo 2002; Sibanda 2004; Malambe 2006, etc.; see also Stahlke 1976). The dissimilation and glide-driven analyses are not necessarily mutually exclusive, either. Khumalo $(1987,1988)$ posits a process of labial dissimilation that creates palatal glides before /w/, with this $/ \mathrm{j} /$ then triggering palatalization (see also Poulos \& Msimang 1998; Kotzé \& Zerbian 2008). What all these approaches have in common, though, is that they take it as a given that the basic pattern is a product of phonology (whether in the form of a rule, or constraint, or whatever else a theory assumes).

The principal alternative to treating labial palatalization as phonological is to treat it as a product of historical changes. This view is taken most prominently by Ohala (1978), who analyzes labial palatalization in Tswana as the end result of a string of historical changes, as in (8) (for further development of the idea and proposal, see Ohala 1981; for other examples of this general approach to labial palatalization in southern Bantu languages, see also Louw 1976; Herbert 1977, 1990; Bateman 2007, 2010, among others.)

$$
\text { \$ } / \mathrm{p}+\mathrm{jw} / \rightarrow \mathrm{pjw} \rightarrow \mathrm{p} \int \mathrm{w} \rightarrow \mathrm{t} \int \mathrm{w} \rightarrow / \mathrm{t} \mathrm{f}
$$

The starting point for this chain is the assumption that the passive suffix historically had a front vocoid component, i.e., an [i] or [j]. Following a voiceless consonant like [p], this vocoid could have been phonetically devoiced, yielding a voiceless glide [j ]. This glide could be misperceived and re-analyzed as a fricative, such as [ $]$ ]. When faced with a disagreeing sequence like $\left[\mathrm{p} \int \mathrm{w}\right]$, listeners might subsequently infer that the labiality of the [p] component of the sequence is a product of unintentional co-articulation with the following [w]. Consequently, listeners might 'undo' this presumed co-articulation, and infer that such a sequence is actually meant to be $\left[\mathrm{t} \int \mathrm{w}\right]$, and that it arises from underlying $/ \mathrm{t} \int+\mathrm{w} /$ (following the mechanism proposed by Ohala 1981). The end result is a situation where passive verb stems that underwent this string of changes have $/ \mathrm{t} \mathrm{f} /$, while their corresponding active forms, not subjected to the same changes, retain $/ \mathrm{p} /$. We can also imagine similar pathways for other bilabials, all stemming from diachronic palatalization induced by a historical [j].

What makes this historical account appealing is that the individual steps in the chain are not only reasonable, but are also supported by comparative evidence. The passive suffix in Xhosa (and other Nguni languages) has an allomorph /-iw-/, which is found with sub-minimal verb stems (Podile 2002; see also Downing 2001; Cook 2013 on Zulu). The general form of the passive also has an /i/ in some more distantlyrelated languages, like Xitsonga (Baumbach 1987). So, $\%$-iw-/ is quite plausible as a historical form for the passive suffix. The intermediate stages of the chain, like $\left[\mathrm{p} \int \mathrm{w}\right]$, are similarly plausible. Labial-coronal sequences like [p $\left.\int\right]$ are attested in some dialects of Setswana, Northern Sotho, Sepedi, and Southern Sotho (Kotzé \& Zerbian 2008). Some dialects of these languages even have variation between forms with a labial first component like [p $\left.\int \mathrm{w}\right]$ and fully-palatalized forms like $\left[\mathrm{t} \int \mathrm{w}\right]$; this seems to fit nicely with the idea that speakers can - and do - re-analyze such forms in the way that Ohala proposes.

The availability of a historical account of labial palatalization undermines part of the motivation for a phonological analysis. If the occurrence of palatalized passive forms can be explained solely by the pathway in (8), then it is not necessarily the case that synchronic phonology actually turns labials into palatals. Instead, it could be that the active-passive pairs are actually not related by a simple phonological mapping. We term this the lexical hypothesis. In this view, the relation between active and passive verbs can be taken

words at the prefix-stem juncture, as the result of m-final prefixes before a w-initial stem (e.g. um-wonyo [úm-wônò] 'kloof, deep gorge'), though w-initial stems are not very common. As far as we know, labial-w clusters never occur morpheme-internally (with the exception of some borrowed stems, like iZimbabwe). 
as a sort of suppletion, on par with English goose geese: one was derived from the other by historical sound changes, but the synchronic grammar does not implement this alternation - at least not as part of the phonology. Under this hypothesis, the phonology of Xhosa does not produce mappings like $/ 6 \mathrm{w} / \rightarrow$ [cw]; rather, speakers store a form like /-łac-w-/ in the lexicon as the irregular passive of /-la6-/ 'stab', and so on for other verbs. The choice between them is an alternation between morphemes or fully-formed lexical items, not a change of one segment into another. (For some previous analyses of Nguni language palatalization along lexical and morphological lines, rather than as part of phonology proper, see O'Bryan 1974; Herbert 1977, 1990; Van der Spuy 2014.)

Both hypotheses have compelling evidence supporting them, and both have unsolved loose ends as well - as much of the previous literature has discussed. The alternations we see in Xhosa look quite unusual, and are at odds with typological norms; if the pattern requires us to expand the scope of what synchronic phonology can do, then we are justified in being skeptical of the phonological hypothesis. By contrast, the historical pathway proposed by Ohala (1978) is made of very reasonable and well-supported steps; the fact that the end result looks phonetically unnatural is not a problem for the lexical hypothesis. On the other hand, the phonological hypothesis connects palatalization to another phonotactic generalization - the systematic absence of $\mathrm{B}+\mathrm{w}$ sequences in Xhosa, even in recent loanwords and in morpho-phonological contexts where there is no palatalization (see footnote 11 above). This doesn't obviously follow from the lexical hypothesis, even in conjunction with the historical pathway in (8). Long-distance palatalization is also problematic to explain as a combination of history and the lexicon alone, without phonology. In examples like /-se6e $\mathrm{e}^{\mathrm{n}} \mathrm{z}-\mathrm{w}-\mathrm{a} / \rightarrow$ [-sec' ${ }^{\mathrm{n}} \mathrm{zwa}$, it seems highly unlikely that listeners would mis-attribute the labiality of the [6] to unintended co-articulation with a following [w] when other vowels and consonants intervene between them, especially since the intervening segments are not discernibly subject to the same co-articulation. ${ }^{12}$

Since both hypotheses have good points, and both have problems, the grammatical representation of the pattern has remained uncertain throughout the previous literature. The diachronic pathway does not rule out a synchronic, phonological, analysis of the pattern; it just makes it less obvious that one is necessary, and suggests that the synchronic status of the alternation could lie in morphology rather than phonology. But even if the pattern does indeed have historical roots, a learner might still represent the pattern phonologically in response to the lack of Bw sequences in the lexicon (for a recent example, see Coetzee 2014 on voicing co-occurrence restrictions in Afrikaans). Since both scenarios are eminently plausible, the goal of our study is to bring new data to bear on the issue of how to pull them apart.

\section{Assessing productivity of palatalization experimentally}

To test the productivity of the labial palatalization pattern - and to distinguish between the phonological hypothesis and the lexical hypothesis - we conducted a 'wug'-type experiment (Berko 1958). On each trial, speakers were shown the active form of a nonce Xhosa verb, and were asked to provide the corresponding passive form. The stimuli were designed such that a palatalization target ( $m b$ or $m$ ) was word final; adding the passive morpheme [-w] could then cause palatalization of the target.

If speakers regularly produce palatalized passive forms of nonce verbs, we can conclude that the phonological hypothesis is correct, since that hypothesis predicts that speakers should generalize their labial palatalization rule to new verbs of the correct shape. If, on the other hand, speakers fail to palatalize novel passive forms, we can conclude that the lexical hypothesis is correct, since lexically stored patterns are not generally productive.

\footnotetext{
${ }^{12}$ Our impression from casual observation is that the intervening segments are not audibly labialized in forms like these, but we leave further testing and confirmation for future research.
} 


\subsection{Stimuli}

Forty nonce verb roots were created, all with CVC structure (the canonical shape of verb roots in Xhosa). Within each root, the vowels were one of $a$ [a] or $o$ [o] (twenty verbs each), and the final consonant was either a "palatalization target" $\left(m b\left[{ }^{\mathrm{m}} \mathrm{b}\right]\right.$ or $\left.m[\mathrm{~m}]\right)$, or an "underlying palatal" $\left(n j\left[{ }^{\mathrm{n}} \widehat{\mathrm{d}_{3}}\right]\right.$ or $\left.n y[\mathrm{n}]\right)(10$ items per final consonant). The underlying palatals were included to ensure that speakers treat underlying palatals faithfully, and for use in a follow-up experiment. In addition to the 40 nonce verb roots, 40 real Xhosa verb roots were included as fillers, most of which contained neither labials nor palatals. ${ }^{13}$

Each stimulus item was put into the inflectional frame iya-___ $-a$, with a prefix iya- [ija-] (SM.9-PRES) and a suffix $-a[-\mathrm{a}]$, producing a verb form approximately analogous to a present progressive. All stimuli were presented in standard Xhosa orthography. ${ }^{14}$

20 nonce roots ended in a palatalization target $\left(m b\left[{ }^{\mathrm{m}} \mathrm{b}\right]\right.$ or $\left.m[\mathrm{~m}]\right)$. When the passive suffix $-w$ - is added to these verbs, the final consonants are put into the conditioning environment for labial palatalization (due to the labial suffix [w]). The remaining 20 nonce roots ended with underlying palatals (10 each of $n y[\mathrm{n}]$ and $n j\left[{ }^{\mathrm{n}} \widehat{\mathrm{d}}\right]$ ), and were included to ensure that speakers treat underlying palatals faithfully.

\subsection{Procedure}

While palatalization has been noted in contexts other than the passive, there appears to be significant lexical variation and irregularity, as noted in section 2.1 above. For this reason, we considered only passive palatalization in this experiment. Participants were shown the real and nonce verbs in Xhosa orthography on a laptop screen in random order. On each trial, participants saw a verb with the iya- [ija-] prefix and a 'final vowel' suffix - $a$ [-a] (normally found in present tense). This inflected verb was followed by an arrow and a blank space surrounded by iya- and - wa as in (9). The suffixal -w- cued speakers to produce passive forms with this /-w-/ suffix; the prefixal iya-serves to hold tense and subject agreement constant. The active and passive forms were labeled with Xhosa language terms for 'active voice' (isixando sokwenza) and 'passive voice' (isixando sokwenziwa - which itself contains the passive verb stem -enziwa).

\footnotetext{
${ }^{13}$ Real-word filler items were chosen based on the presence or absence of certain obstruents of interest for an unrelated study. Among these items, four contained palatalization undergoers (two medial $\left[\mathrm{p}^{\mathrm{h}}\right]$ and one medial [b], as well as one root-final [6]). One item had a final [n], a segment which can be the result of the palatalization process. Apart from these items, no other filler words contained medial or final consonants that can undergo or result from the relevant palatalizing pattern. We note that some words had initial [c'], however root-initial consonants are unaffected by palatalization. A total of 12 filler items had either an initial [c'], or another palatal consonant that is not part of the palatalization pattern under discussion (i.e. $\left[\mathrm{j} J_{\mathrm{J}} \mathrm{c}^{\mathrm{h}} \mathrm{e}^{\mathrm{n}}\right]$ ).

One stimulus item, kwanya [-k'wana], had a [w] in the root. Impressionistically, this form appeared to us to be a more difficult choice than other stimuli. Several speakers produced its passive as [-k'anwa], with apparent labial dissimilation in the root $(*$-kwanwa). This was coded as a reading error, but we mention it here for interest.

${ }^{14}$ Orthography is one reason why some speakers may have unexpectedly high error rates. In the standard Xhosa orthography, aspirated stops are represented as digraphs $\langle\mathrm{ph}$ th $\mathrm{kh}\rangle$; however, older orthographic conventions render them as $\langle p t k\rangle$. The older convention is still widespread in personal names, and is commonly seen on signs and in other less formal contexts - where it may carry covert prestige. Consequently, the letters $\langle p t k\rangle$ could reasonably be interpreted as either [ $\left.\mathrm{p}^{\prime} \mathrm{t}^{\prime} \mathrm{k}^{\prime}\right]$, or as $\left[\mathrm{p}^{\mathrm{h}} \mathrm{t}^{\mathrm{h}} \mathrm{k}^{\mathrm{h}}\right]$, depending on the orthographic convention assumed. Aspirated stops seem much more frequent, particularly in stem-initial position. For consistency, trials where a participant read $\langle p t k\rangle$ as aspirated were coded as reading errors, and excluded from the analysis - but this means the high number of errors should not be regarded as an indication that those speakers found the task difficult to do.
} 
Example of stimulus presentation

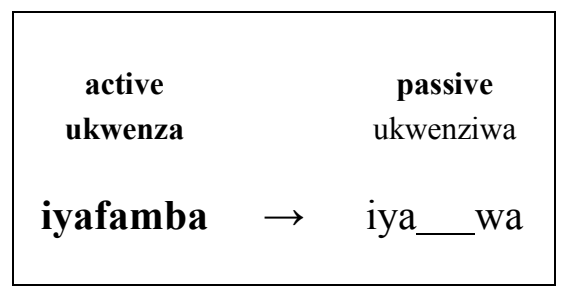

Before experimental trials began, speakers were shown 3 examples with real verbs and their passive counterparts in order to illustrate the active/passive responses desired. This was followed by practice with 9 real word items. Speakers then read the nonce word aloud, followed by saying aloud their passivized form of the verb.

On trials with a root-final bilabial (a palatalization target), speakers must decide whether to apply labial palatalization, since the passive -w- suffix serves as a trigger for this process. If speakers apply labial palatalization to nonce words, this suggests that the phonological hypothesis is correct, and that speakers' knowledge of labial palatalization is based on a phonological rule/process. If, on the other hand, speakers do not palatalize root final labials followed by a triggering -w- suffix, it can be inferred that their knowledge of the labialization process is lexically based, and will only be applied to words stored in their lexicon with the palatalized segment already in place.

\subsection{Participants and recording}

In the initial round of testing, 18 native speakers of Xhosa participated in this experiment (12 female, 6 male). Speakers ranged in age between 17-46 years (mean: 27.11 years). At the time of the experiment, all of these participants lived in South Africa's Eastern Cape, in the area of Makhanda (formerly named Grahamstown; iRhini [í-xìní] in Xhosa). Two speakers indicated that they had grown up in other places: one in Johannesburg, and one in Cape Town. These participants all spoke Xhosa as their primary home language, and all also spoke at least some degree of English. Other languages that some number of the participants reported that they had some knowledge of are Zulu $(n=6)$, Sesotho $(n=5)$, Afrikaans $(n=3)$, Setswana $(n=2)$, Sepedi $(n=1)$, Chichewa $(n=1)$, and Portuguese $(n=1)$. This high degree of multilingualism is not at all surprising, given the context of high linguistic diversity in South Africa. The languages recognized as official at the provincial level in the Eastern Cape are Xhosa, Afrikaans, English, and Sesotho, and Zulu verges on mutual intelligibility with Xhosa. There is no apparent pattern of relatedness between speakers' behaviour with respect to palatalization and the second languages they reported speaking, and also no apparent pattern of correlation with age, or hometown.

In order to examine whether palatalization differed between dialects or was affected by exposure to English, a second set of data was collected from 7 speakers who identified themselves as speaking isiMpondo, another Nguni variety commonly considered a dialect of Xhosa that shares some features with Zulu (Nyamende 1994; see also Cantrell 1946). These speakers were recorded near Port Saint Johns (approximately $500 \mathrm{~km}$ northeast of Makhanda), in the area formerly designated as Transkei - a Xhosaspeaking 'homeland' during the Apartheid regime. (Data from one speaker was discarded, as a noisy environment during recording made analysis impossible). These speakers differ from the Makhanda group in having little or no understanding of English, and our experiment instructions were explained in Xhosa for these participants. Speakers from the first set of Makhanda data are given numbers 1-18, while the Mpondo speakers are given letters A-I.

\subsection{Evaluation and coding of responses}

The authors listened to recordings of participants' responses, marking whether or not they had produced the predicted palatalized form. Additionally, items where the speaker failed to produce the $-w$ - passive 
morpheme - either replacing it with a different morpheme or failing to add a morpheme - were marked and excluded from analysis (96 items out of 993). Some participants added not just the passive, but also another extension, most commonly the causative -is- (117 items). That is, when presented with an active nonce item like iyabanya 'it is banya-ing', some speakers in some trials produced responses like iyabanyiswa, which could be translated as 'it is being made to banya'. We regard this as a perfectly reasonable interpretation of the task based on the instructions given. Since suffixes like -is- are reported to not affect palatalization (Louw 1976: 247, etc.), we included these items in our analysis. The rates of palatalization in these extended forms did not differ significantly from items that had only $-w$-added.

\section{Results}

In this section, we discuss the results of the experiment described above. We begin in section 4.1 by describing the overall pattern of the results, pooled across all speakers. Section 4.2 lays out inter-speaker differences, section 4.3 shows the results by item, and section 4.4 shows the results for each speaker by item.

\subsection{Results pooled across speakers}

Across all speakers, nonce items with final underlying labials were palatalized $76.05 \%$ of the time (e.g., $i y a-f a m b-a \rightarrow$ iya-fanj-w-a), which is above $50 \%$ (i.e. greater than chance). (For comparison, underlyingly palatal items were produced as palatals $100 \%$ of the time, exactly as expected.) In the remaining $23.95 \%$ of cases participants produced the nonce items with their target consonant unchanged, yielding a putatively illicit phonotactic Bw sequence (e.g., iy $a-f a m b-a \rightarrow i y a-f a m b-w-a$ ). These results are shown in Figure 1.

Trials palatalized/not palatalized

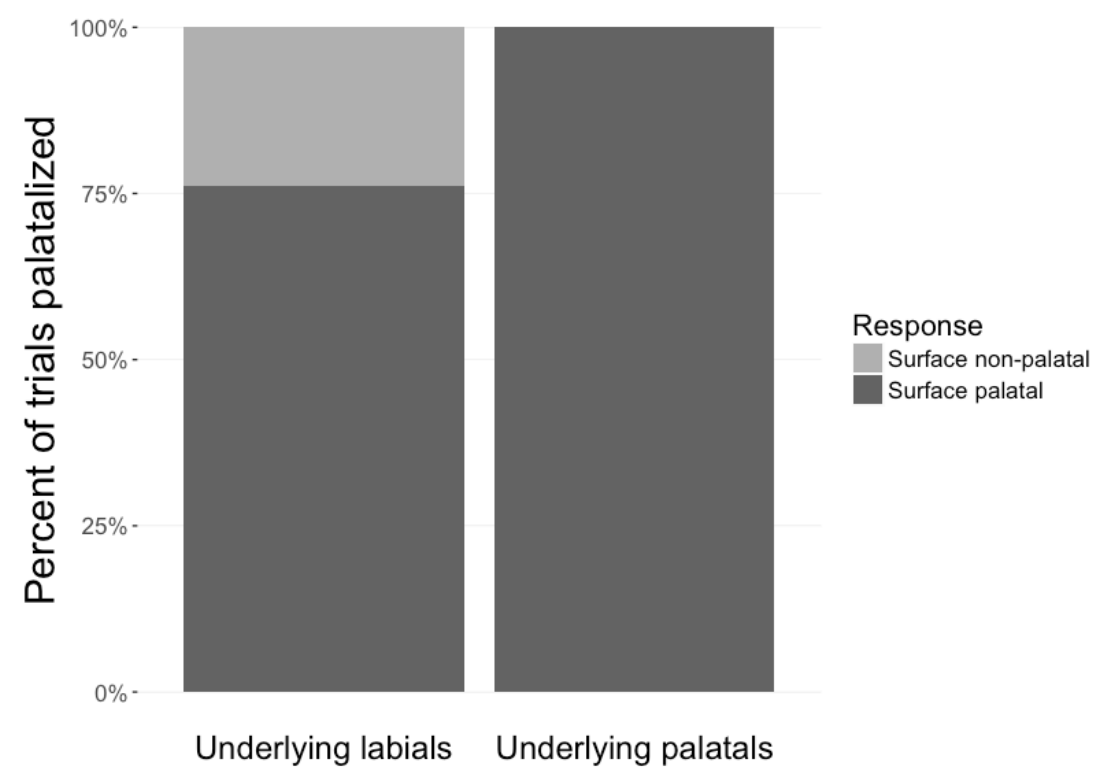

Figure 1: Percent of trials produced as palatal.

\subsection{Inter-speaker differences}

The percent of trials with underlying labials palatalized by each speaker ranged from $0 \%$ to $100 \%$. This result is shown in Figure 2. The speakers can be grouped into three broad categories: (a) those who almost never palatalize nonce words (speakers 7 and 9; "non-palatalizers"), (b) speakers who palatalize between 
$30 \%-85 \%$ of nonce words (speakers $4,5,6,810,11,12,14, \mathrm{D}$, and F; "occasional palatalizers"), and (c) speakers who palatalize $100 \%$ of nonce items (speakers 1, 2, 3, 13, 15, 16, 17, 18, A, C, G, and I; "palatalizers").

\section{Trials palatalized}

By speaker

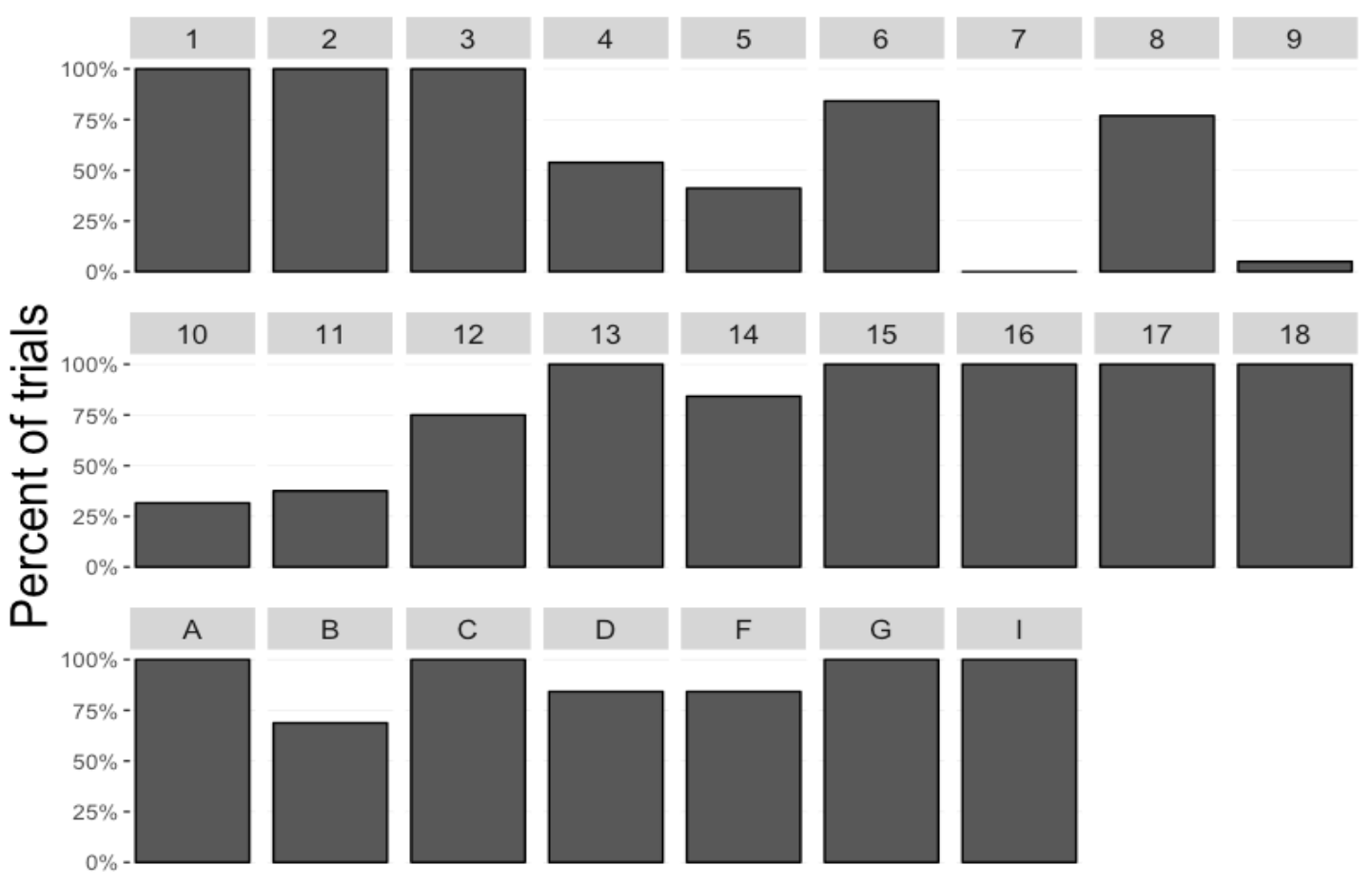

Figure 2: Percent of trials palatalized by speaker

\subsection{Effect of dialect}

As noted above, the first 18 speakers grew up predominantly in the area of Makhanda, while the remaining speakers came from the area around Port St. Johns and self-identified as speaking the isiMpondo dialect (in addition to or instead of isiXhosa). We note that there is no clearly categorical difference between the two sets of speakers (and as such, results reported below are pooled across the two participant groups). It is perhaps notable that all Mpondo speakers palatalized some of the time, but we note that this group still shows variation, with some speakers palatalizing $100 \%$ of the time, with others being less systematic. The Mpondo speaker with the lowest rate of palatalization, speaker B, palatalized $68.75 \%$ of the time (compare to the Makhanda speakers, where two speakers practically never palatalize, and others palatalize at rates as low as $31 \%$ ).

\subsection{Inter-item differences}

Across all speakers, items ranged from a low of $56.25 \%$ palatalized (iyahama) to a high of $95.25 \%$ (iyantloma). (As noted in section 4.1, the mean across all speakers and items was $76.05 \%$ palatalized.) This result is shown in Figure 3. A plurality of items $(n=11)$ were between $60 \%-79.99 \%$ palatalized; one item was between $40 \%-59.99 \%$ and eight items were between $80 \%-100 \%$ palatalized. 


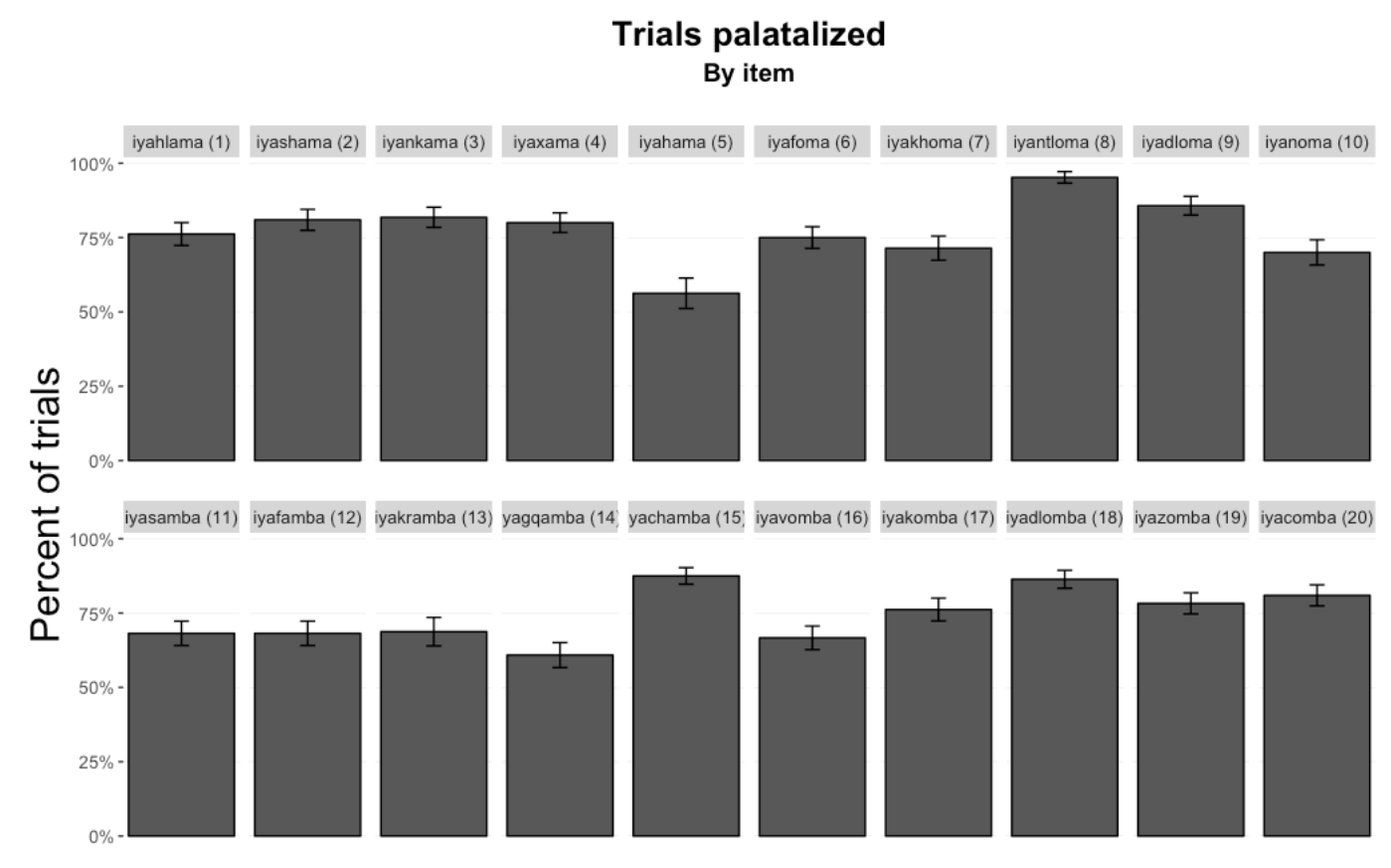

Figure 3: Percent of trials palatalized by item

\subsection{Speaker-item combinations}

The mosaic plot in Figure 4 combines the results of the by-item and by-speaker analyses above. Each individual tile represents one trial by one speaker (e.g., the top-left tile represents speaker 7's production of iyantloma), which was either palatalized (dark grey) or was not (light grey). Speakers and items are each ordered from least palatalization (left, bottom) to most (right, top).

As can be seen in the plot, non-palatalizers fail to palatalize almost all items, while full palatalizers palatalize almost every item. Similarly, some items are almost always palatalized (e.g., item 8 iyantloma), while others are palatalized by only half of the speakers (e.g., item 5, iyahama). 


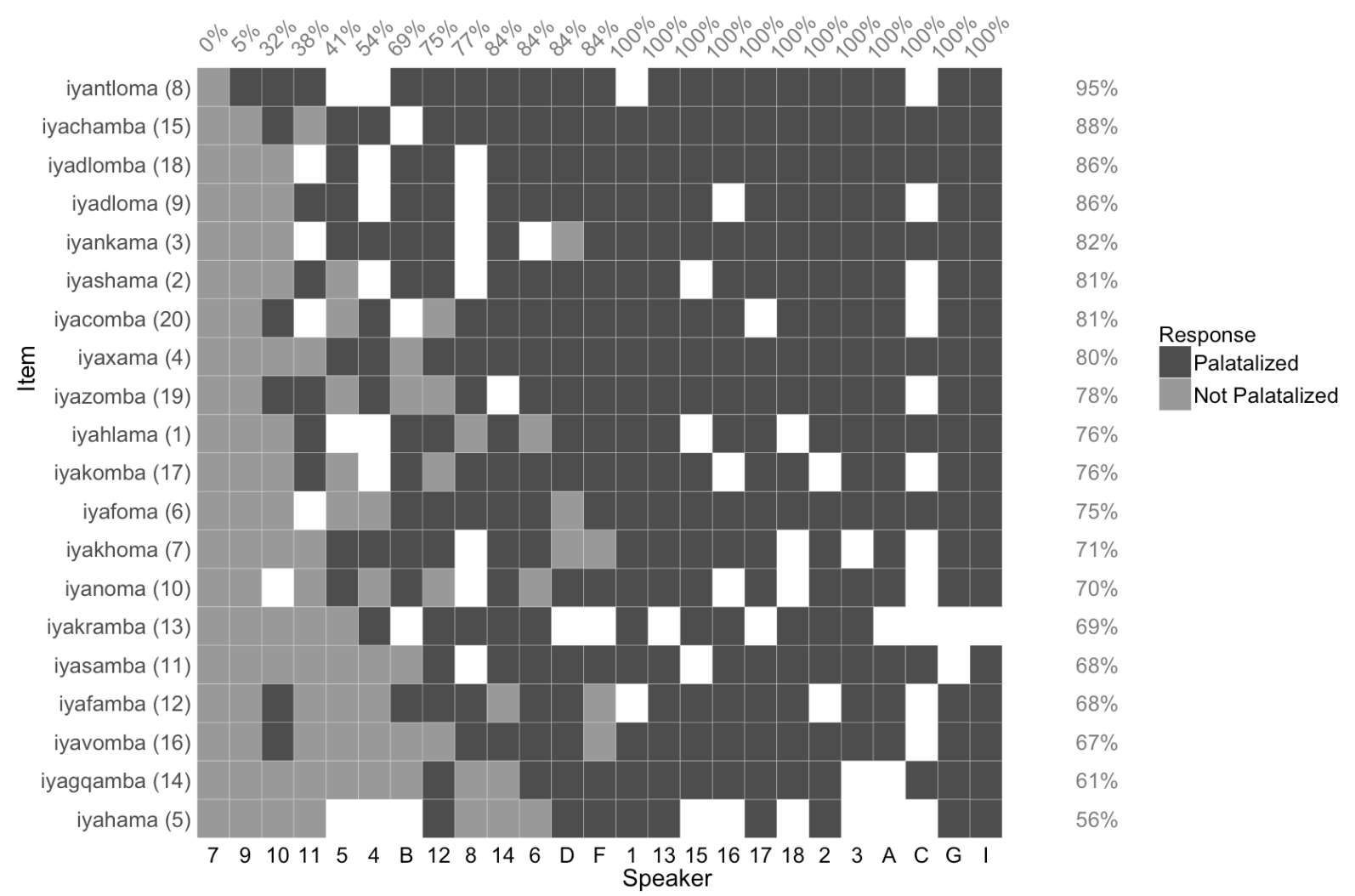

Figure 4: Items palatalized and not palatalized by speaker and item. White tiles represent reading or speech errors which were excluded from the analysis.

\section{Interpretation and discussion}

\subsection{Speakers can have different grammars}

Our interpretation of the results is that labial palatalization works in different ways for different speakers. The speakers we classify as palatalizers apply palatalization with complete systematicity in the lab. This is the expected result if the palatalization pattern is a product of regular phonology. On the other hand, the speakers we classify as non-palatalizers do not palatalize in nonce words. This is the expected result if palatalization is extra-phonological. These non-palatalizing speakers did produce palatalized forms as expected in practice items and in at least some real-word filler items; it is not the case that they simply do not have palatalization (on this, see Section 5.3.3). Rather, it seems that they palatalize only in actual words, and not in nonce ones. This makes sense if these speakers have fully-formed palatalized passives stored in their lexicons, and do not have any palatalization process in their phonological grammars.

The presence of both palatalizers and non-palatalizers in our sample underscores a much broader point made in previous work: not all speakers of a language have the same phonological system. This is not a novel conclusion (see, for instance, de Lacy 2009 on the point in abstract, and Zsiga et al. 2006; Coetzee \& Pretorius 2010; Gouskova et al. 2011 for a concrete example). It is also a point that is obscured by pooling data across speakers. The group as a whole palatalizes approximately $75 \%$ of the time. But within the group of participants we sampled, only a small minority of speakers (4 out of 25) are anywhere close to this rate. The much larger majority of speakers either palatalize all the time, or palatalize far less often. This makes sense if speakers have internalized different representations of the pattern. That, in turn, entails that the same pattern is learned by some speakers as a part of phonology, and by other speakers as a lexical one that does not generalize. 


\subsection{Occasional palatalizers and the role of analogy}

The grammatical representation of palatalization for the group of occasional palatalizers is less clear than for the palatalizers or non-palatalizers. We see two possible explanations for their behavior. One is that they are essentially phonological palatalizers who internalized palatalization as a gradient pattern rather than a systematic one. As such, they do generalize the alternation to nonce words, but do so at a rate less than $100 \%$. The other possibility is that they are essentially non-palatalizers, who produce palatalization in nonce items by analogy to real words that undergo palatalization. ${ }^{15}$

The latter, analogy-based, interpretation finds support in some previous work on labial palatalization in other Nguni and Sotho languages. O'Bryan (1974), for example, argues that long-distance palatalization in non-derived stems happens by analogy with long-distance palatalization in derived stems, which in turn happens by analogy with local palatalization in non-derived stems. That is, palatalization can happen with a root containing a medial labial like/-sebenz-/ 'work' because it also happens with medial labials in derived stems like /-bem-el-/ 'smoke for', which in turn can palatalize because it is derived from /-bem-/ 'smoke', where the labial is root-final and undergoes palatalization more transparently. Along similar lines, Khumalo (1987) argues that a derived morphological structure is projected onto non-derived stems by analogy: /-se6enz-/ is analyzed as ((se6)enz) despite the absence of a simple root /-se6-/. Herbert (1977, 1990) also takes a similar view in arguing that palatalization is non-phonological. Moreover, he follows O'Bryan in attributing the less-than-systematic occurrence of long-distance palatalization to it being a product of morphological analogy rather than part of phonology. So, if the group of occasional palatalizers are doing local palatalization sporadically, it's entirely reasonable to wonder whether they might be doing all palatalization by analogy.

We can also envision a more extreme position: what if all speakers are producing palatalization by analogy, and they differ only in how readily they analogize?

\section{Testing analogy post hoc}

\subsection{Occasional palatalizers and strong analogical bases}

The by-item comparisons summarized above offer one potential way to assess whether our participants are working by analogy. If speakers are producing palatalized nonce items by analogy with real words, it follows that the palatalized forms they produce should cluster around real-word analogical bases. That is, if occasional palatalizers are working by analogy, then they should be more likely to palatalize nonce items that have a stronger similarity to real words that frequently undergo palatalization, and vice versa.

What exactly makes a good analogical base, and how such determinations are made, are by no means straightforward or settled questions (for some of the discussion, see Wagner 1969; Mańczak 1980; Kuryłowicz 1995; Albright 2010; Moore-Cantwell 2016; Guzmán Naranjo 2017). But as a first approximation, we can look at whether the occasional palatalizers treated nonce words differently based on their phonotactic shapes. Irrespective of the proper characterization of analogical base strength, any asymmetry based on the phonotactic shape of roots should emerge in our results as an asymmetry between sub-groups of our nonce items, as an effect of the quality of the root-final consonant or the preceding vowel.

Naively, one might expect that prominence as an analogical base might follow from frequency. That is, if speakers encounter palatalization of /...am-wa/ to [...an-wa] much more often than they encounter / . .om-wa/ $\rightarrow[\ldots$ on-wa $]$, then we might expect them to palatalize nonce roots of the shape /-Cam-/ more consistently than nonce items of the shape /-Com-/. In the hopes of gaining an approximate assessment of these sorts of relative frequencies, we consulted the National Centre for Human Language Technology (NCHLT) isiXhosa morphologically tagged text corpus (Eiselin \& Puttkammer 2014). This corpus, the largest publicly-available morphologically annotated corpus we know of for Xhosa, contains approximately

\footnotetext{
${ }^{15}$ We note that these are not necessarily mutually exclusive possibilities: it could be that both types of speakers exist, and that the occasional palatalizers are split between the two.
} 
45,000 words, but there are only 30 tokens of palatalized passives (and no tokens of root-final labials that fail to palatalize before the passive -w-). All 30 tokens are built on just 8 verb roots. ${ }^{16}$ While this is very little data to reason from, particularly about relative frequency of lexical items, we did observe that $/ \ldots$ $\mathrm{a}^{\mathrm{m}} \mathrm{b}-/$ was most frequently palatalized (17 of $17 / \ldots \mathrm{a}^{\mathrm{m}} \mathrm{b}-/$ tokens in passives palatalized), followed by /... am-/ ( 5 of 10 tokens), and then /...om-/ (3 of 10 tokens); passive forms of / ...o $\mathrm{m}$ b-/ roots were not attested in the corpus, palatalized or otherwise. ${ }^{17}$ None of the occasional palatalizers matched this order in their relative frequency of palatalization.

Figure 5 below shows the relative palatalization rates for three of the occasional palatalizers (speakers 4 , 5, and 6), across nonce items with different root-final consonants and different root vowels. Some speakers appear to have non-random patterns here. For example, speaker 6 palatalizes nonce items with $\left[{ }^{\mathrm{m}} \mathrm{b}\right]$ more often than those with [m]. But speaker 5 does the opposite, palatalizing [m]-final nonce items much more often than $\left[{ }^{\mathrm{m}} \mathrm{b}\right]$-final ones. Meanwhile, speaker 4 palatalizes more often for [...am-a] and $\left[\ldots \mathrm{o}^{\mathrm{m}} \mathrm{b}-\mathrm{a}\right]$ roots, and much less often for $[\ldots \mathrm{a} \mathrm{m}-\mathrm{a}]$ and $[\ldots \mathrm{om}-\mathrm{a}]$. While each of these three speakers seems to have some kind of skew in their rates of palatalization depending on the shape of the nonce root, they are not skewing in the same way. The result evident here is that if these occasional palatalizers are producing palatalized forms by means of analogy, they clearly are not converging on the same analogical base(s).

\section{Trials palatalized/not palatalized}

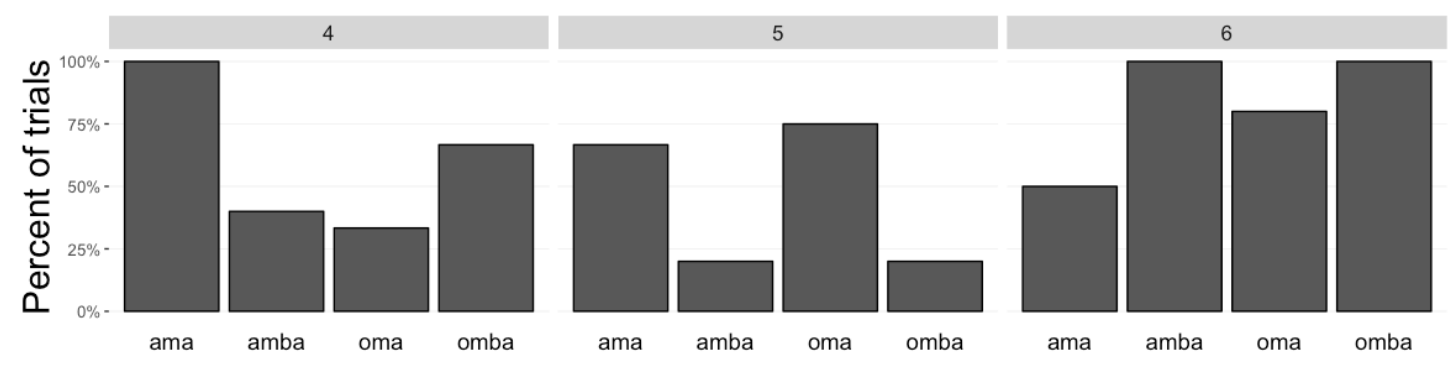

Figure 5: Rates of palatalization for speakers 4,5 , and 6 by root-final vowel consonant and vowel

Similarly, Figure 6 shows the rates of palatalization for speakers 8 and 12. While speaker 8 palatalizes more frequently in forms with stem-final [a] (ama, amba), speaker 12 palatalizes more frequently in forms with stem-final [o] (oma, omba). This pattern is reflected in the fact that the graphs for speakers 8 and 12 are mirror images of one another. In other words, speakers 8 and 12 have almost precisely the opposite pattern from one another - further evidence that speakers are not converging on similar analogical bases.

\footnotetext{
16 The NCHLT Xhosa corpus contains 10 sequences of a labial followed immediately by $w$. One of these is an acronym EPWP; one is a sequence of the relative agreement marking yom- preceding a w-initial verb; the other 8 are all tokens of Zimbabwe.

We also made a cursory analysis of the Ukwabelana tagged corpus of Zulu (Spiegler, Van der Spuy \& Flach 2010), which provides a list of 10,000 orthographically distinct morphologically-parsed Zulu words. This list includes 765 tokens of the passive suffix. Of these, only 54 follow a stem-final palatal, and thus are potential cases of palatalization of a final labial. There are 0 instances of non-palatalized root-final labials followed by the passive suffix (i.e., failure of palatalization).

${ }^{17}$ Another obvious candidate for good analogical bases would be density of the lexical neighborhood. Thus, the more actual words a nonce item resembles that actually undergo palatalization, the more likely the nonce item should be to palatalize. We know of no previous studies of lexical neighborhood density in Xhosa, so data on this point is not readily available for comparison. It would stand to reason, however, that any large asymmetry in lexical neighborhood would likely also manifest in corpus frequency, which we have considered here.
} 
Trials palatalized/not palatalized

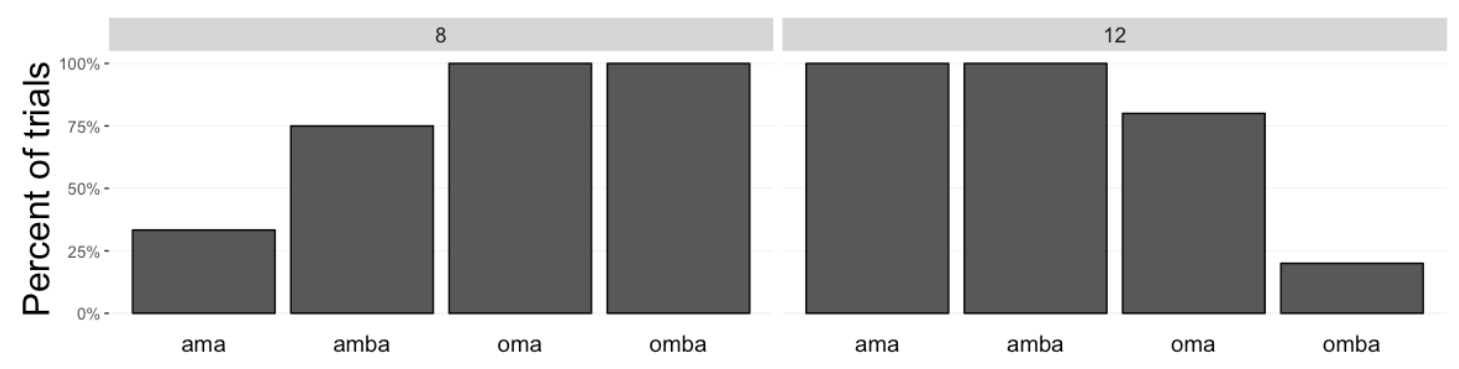

Figure 6: differential palatalization rates across groups of items with common phonotactic shapes

\subsection{Testing speakers' propensity to analogize: cross-task comparison}

When followed to its logical extreme, the notion that speakers might palatalize nonce items by analogy with real words leads to an intriguing follow up question: could it be that all the speakers in our sample were actually producing palatalized forms by analogy? If so, it would mean that the palatalizers and nonpalatalizers don't really have different phonological grammars; instead, they could just differ in how readily they extrapolate from real words to nonce items. The full palatalizers would then be at the top end of this spectrum, and the non-palatalizers at the bottom. A similar alternative interpretation is that the inter-speaker differences are task effects. It could be that the differences in rates of palatalization arise not because speakers have different grammars, but rather differences in how well they understand the task.

While we did not design our experiment to test for these possibilities, we have the means to do so post hoc. Each of the participants in the Makhanda group also did another, unrelated, wug test experiment during the same experimental session. As such, we can compare speakers' rates of palatalization in this experiment to how they treated other kinds of nonce words exhibiting other kinds of patterns. If variation in the data is due to variation in how speakers understood the task, then variation in the labial palatalization experiment should correlate with variation on other experimental wug-test tasks.

The other experiment we compare to was designed to test how productively speakers apply lengthconditioned alternations in noun class prefixes (patterns described by Claughton 1992: 57; Tshabe et al. 2006). Every noun in Xhosa normally bears a prefix, which marks the class that noun belongs to. Nouns of class 9 normally bear the prefix $i(N)-{ }^{18}$ These nouns have regular plurals in noun class 10 , but the class 10 prefix has two allomorphs: it appears as $i i(N)$ - by default, or as $i z i(N)$ - with monosyllabic roots. Similar allomorphy happens with the prefix for noun class 5 , which is $i$ - by default, or ili-for monosyllabic roots. Nouns of class 5 make their regular plurals in class 6 , which has the prefix ama-. This allomorphy is shown in (10) and (11); in both cases, we find the default forms of the prefixes with polysyllabic roots, and the longer forms of the prefixes with monosyllabic roots.

(10) Class 9 singulars, with allomorphy in Class 10 plurals
a. ín-t'ó
$\rightarrow$ ízin-t'ó
'thing(s)'
$\mathrm{VCV}^{\mathrm{N}}+\mathrm{CV}$

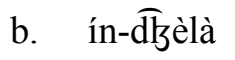
$\rightarrow$ ín-d̂̉zèlà
$' \operatorname{road}(\mathrm{s})$ '
$\mathrm{V}^{\mathrm{N}}+\mathrm{CVCV}$

(11) Class 5 singular allomorphy, with Class 6 plurals
a. ilí-cè
$\rightarrow$ amá-cè
'stone(s)'
$\mathrm{VCV}+\mathrm{CV}$
b. í-|èphé
$\rightarrow$ ámá-|èp ${ }^{\text {hé }}$
'spoon(s)'
$\mathrm{V}+\mathrm{CVCV}$

\footnotetext{
${ }^{18}$ The ' $\mathrm{N}$ ' in the class 9 and class 10 prefixes is a nasal that is normally homorganic with the following consonant. This nasal is absent before certain consonants, and in many loanwords (including recent borrowings, which systematically have $i$-).
} 
If speakers are all producing palatalization by analogy, and merely differ in how readily they analogize, then we might expect rates of palatalization to correspond to performance of the length-based prefix allomorphy. The speakers who had high rates of palatalization would have to be regarded as people who are very good at analogizing known patterns to novel words; on the other hand, those with low rates of palatalization would be people with less propensity to analogize. By the same token, if some speakers are simply better at performing wug test tasks, then they ought to be highly systematic in both palatalization, and length based allomorphy. The resulting predictions are (i) that speakers who palatalize systematically in nonce words should also do the length-based prefix alternations in nonce words; and (ii) speakers who are non-palatalizers in nonce words should likewise fail to generalize the length-based alternations in nonce words.

Neither of these predictions are borne out in our results.

The length-based allomorphy patterns involve two facets. To completely match the generalizations reported in previous literature, speakers must supply short prefixes when prompted with long roots, and long prefixes when prompted with short roots. We combined these into a single 'percent correct' metric. These percent correct scores were calculated as the sum of trials where a speaker applied the pattern as expected, divided by the total number of trials. This is obtained from the sum of trials where a participant applied long prefixes to monosyllabic roots and applied short prefixes to disyllabic roots, divided by the sum of the total number of short roots and the total number of long roots. Trials where the speaker produced a form of a different noun class than the one expected were excluded from both of these counts.

Figure 7 plots speakers' rate of labial palatalization in the experiment described above (on the y axis) versus how systematically speakers produced the expected alternations in the length-based allomorphy task (x axis). As can be seen in the figure, there is not a clear relationship between performance in the two tasks $(\mathrm{r}=0.076, \mathrm{n} . \mathrm{s}$.). For example, the non-palatalizing speakers 16 and 18 produced the appropriate lengthbased allomorphy approximately $50 \%$ of the time while palatalizing less than $10 \%$ of the time. These speakers can be contrasted with speaker 5 who palatalizes $100 \%$ of the time yet produced the appropriate length-based allomorph only about $10 \%$ of the time.

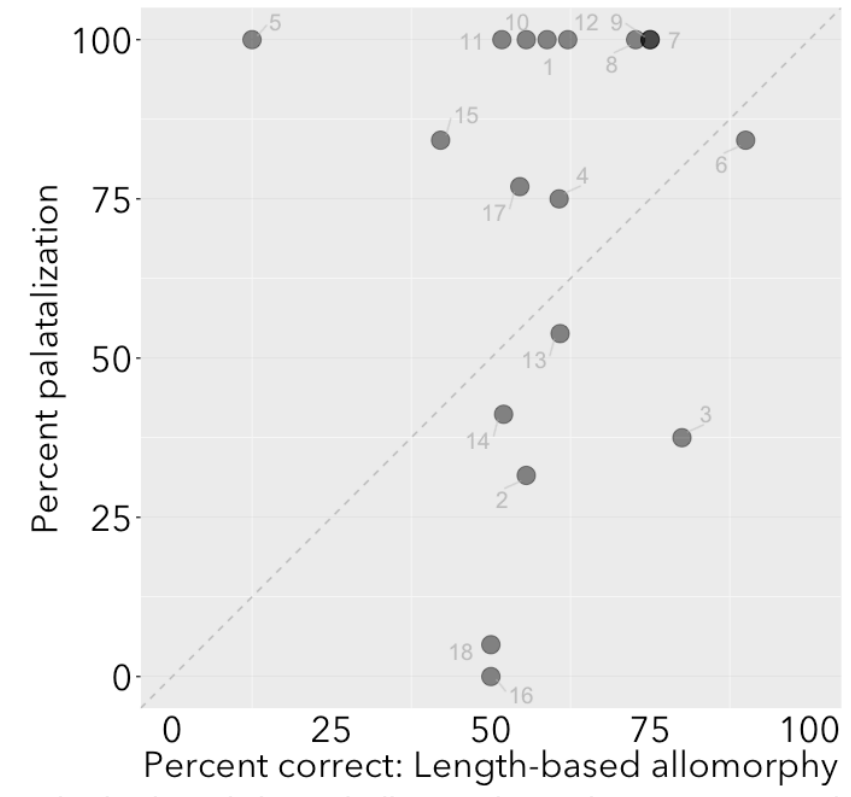

Figure 7: Percent correct in the length-based allomorphy task vs. percent palatalization in the current experiment. Speaker numbers are shown next to their associated data points in the plot.

While post-hoc comparisons of this sort are admittedly preliminary and somewhat speculative, they do suggest that the differences we observe between the palatalizers and non-palatalizers are really differences in phonology, i.e., they are grammatical differences. If they were due to some extra-grammatical factor 
such as propensity to analogize from real words to nonce items, or aptitude at interpreting and performing arbitrary wug-test tasks in a laboratory setting, then we ought to see the same participants behaving the same way across the two experiments. Similarly, if palatalization were being produced entirely by analogy, as some previous analyses have suggested (e.g. Herbert 1990), then we should also expect to see a strong correlation between performance across different wug tasks. This is not the case, which suggests that the differences in rates of palatalization are really the result of inter-speaker variation in the phonological grammar. ${ }^{19}$ In other words, it is not the case that these speakers regularly use analogy to figure out novel phonological patterns. It is also not the case that regular palatalizers are simply at ceiling because they have an easy time with wug test tasks or were more comfortable in the test environment.

\subsection{Testing speakers' propensity to analogize: comparison to real word items}

As noted by the editor, the evidence in the preceding sections regarding speakers' ability to analogize to other forms based on unrelated tasks leaves open the possibility that the palatalization task was difficult or that speakers do not apply this palatalization process reliably even in real words. To address this issue, we discuss here the performance of the speakers on real word items from the practice session and from fillers that match the phonological environment required for the palatalization process. This set of real words is small -3 practice items and 3 filler items - but we present these results which, in concert with the discussion in the preceding sections, suggests to us that the results of the experiment are likely generalizable to both real and nonce words.

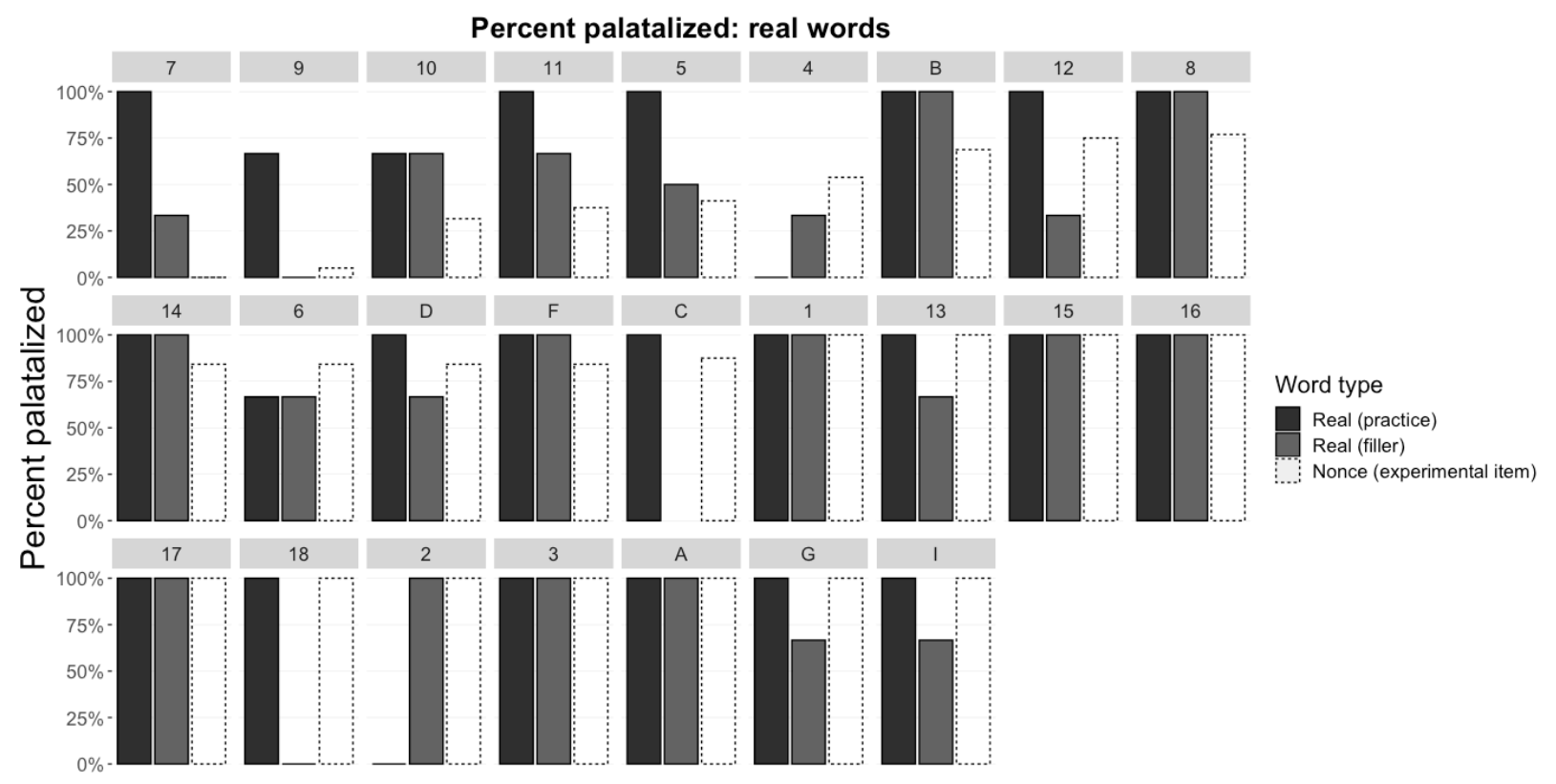

Figure 8: Percent of items palatalized among real words (practice and filler). Percent of nonce items palatalized in the main task are provided in the dotted bars to facilitate comparison.

Figure 8 shows the percent of these real word trials each participant palatalized, ordered from least to most palatalization in the main task, separated by practice vs. filler. Results from the nonce words in the main experimental task are provided in the dotted bars for purposes of comparison. As can be seen in the figure, most speakers palatalized all items in the practice session (with the exception of speakers 9, 10, 2,

${ }^{19}$ We cannot rule out the logical possibility that palatalization in nonce words operates by analogy, while lengthbased allomorphy is true phonology. The range of variation in our allomorphy, and in particular the extent to which speakers did not conform to the expected alternation suggests that the length-based alternations are far less regular one way or the other than palatalization. 
4, and 6), while the rate of palatalization in the filler items is more variable. We believe this is due to the fact that participants were coached through the practice items (e.g. they received prompting or explanation from the investigators if they had apparent trouble understanding the task, made reading errors, or failed to palatalize). Since palatalization rates are largely at ceiling for the practice items, we turn to the filler items to investigate whether there is a relationship between performance on real (filler) words and performance on nonce items from the main experiment.

Figure 9 plots the relationship between palatalization of nonce words in the main experiment vs. palatalization of filler words. There is clear pattern in which points fall roughly along the diagonal line representing equal proportion of palatalization across these two categories $(r=0.55, p<0.01)$. Most notably, 7 speakers palatalized $100 \%$ of the time in both tasks (large dot in the upper right) suggesting that the experimental task reflects their likelihood to palatalize in both nonce and real words. Only one speaker shows a clear, substantial difference between their performance on these two categories of words: the speaker in the top left (speaker 18) palatalized 100\% of the time on the nonce items in the main experiment, but $0 \%$ of the time for the three filler words. We suggest that this is a chance occurrence, given that only 3 filler items are included in this sample.

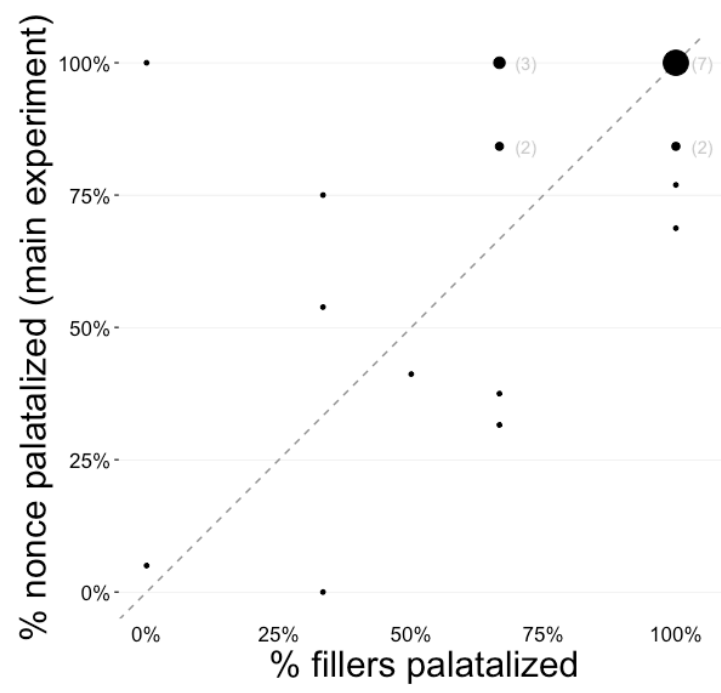

Figure 9: Percent of nonce items palatalized in the main experiment vs. percent of real filler items palatalized. Each dot represents one speaker, except where gray numbers indicate the number of observations at each point is greater than 1.

\section{Questions for future research}

\subsection{Analyzing intermediate speakers}

While some speakers palatalize $100 \%$ of the time $(1,2,3,13,15,16,17,18, \mathrm{~A}, \mathrm{C}, \mathrm{G}, \mathrm{I})$ and others almost always fail to palatalize $(7,9)$, there are intermediate speakers who palatalize at rates ranging from $31.58 \%-$ $84.21 \%$. The palatalization rates of these intermediate speakers could be modeled quantitatively in any number of constraint-based theories, such as variations on OT that allow flexibility in constraint ranking (e.g. Boersma 1997; Boersma and Hayes 2001; Nagy and Reynolds 1997; Antilla 1997; Hayes 2000), as well as variations on Harmonic Grammar (e.g. Boersma and Pater 2016; Goldwater and Johnson 2003; Hayes and Wilson 2008). A fully developed theory of variable phonology is not within the scope of this paper, but if we interpret these speakers as having an inherently variable phonology, then there is no shortage of proposals that might be put to work to model our results. 
A similarly open question concerns how representative this gradience is, and what factors affect it. We know of no previous work on Xhosa that quantifies the frequency of palatalization (or lack thereof) in passives. Some other previous studies of Southern Bantu labial palatalization note variation in the lexicon for diminutives and locatives, as was discussed in section 2.1 above (see Louw 1976: 244-246 on Xhosa; Herbert 1990: 76-77 on Zulu; Tswana, Sibanda 2004, Ch. 5 on Zimbabwean Ndebele; Malambe 2006 on Siswati). Sibanda's (2004) statistical analysis goes a step further in examining the effects of phonotactic stem shape, observing lexical variation in the treatment of root-medial labials, in passive stems of the shape /-CVBVC-w-/. Sibanda (2004: 170ff) also reports that such root-medial labials are palatalized either obligatorily, or optionally, or not palatalized, depending on the verb root. This is plausibly true for at least some speakers of Xhosa as well. ${ }^{20}$ But, as thorough as Sibanda's examination of variation across lexical items is, there is little that can be extrapolated from it about variation across different speakers.

One curious pattern amid the previous reports of optionality in labial palatalization is that variation does not occur when a surface Bw cluster would result. Rather, we find variation and optionality in passives only for long-distance palatalization, i.e., for root-medial labials that are never directly adjacent to the passive [-w-] suffix. In other cases of variation, such as diminutives and locatives, the attested variants include either an overt $[\mathrm{w}]$, or a bilabial - not both. This generalization is curious when compared to our findings: we find that some speakers exhibit variation even in non-long-distance contexts, and even when the overt passive [-w-] creates a surface $\mathrm{Bw}$ cluster. It seems plausible that speakers might naturally analogize the effects of a local phonotactic prohibition like *Bw to produce alternations even in extended verbs (e.g. krob-is-a $\sim$ kroty-is-w- $a$, where the causative suffix -is-intervenes between the passive -w and the stem labial); this has ample precedents elsewhere in Bantu (see Hyman 2003). But, we find it odd that any speaker would both (i) generalize a phonotactic constraint against Bw clusters to apply even to nonlocal B...w sequences, while also (ii) freely violating the local version of the same ${ }^{*} \mathrm{Bw}$ constraint in nonce words.

Many other questions remain to be answered as well, of course. Do speakers typically agree on the behavior of any given verb root? Is there gradience in the judgments of individual speakers? Is there any variation in the frequency of palatalized and non-palatalized forms with those verbs that admit optional palatalization? Do speakers show different rates of palatalization in local versus long-distance palatalization? Our experiment was not constructed to answer these questions, but we hope that other researchers might follow up on them in future studies of Xhosa or other Nguni languages. Also worthy of study is frequency of palatalization in corpora, if and when sufficiently large corpora become available in the future.

\subsection{Effects of task type?}

The task employed here was a classical wug-style task, in which speakers produced nonce items in targeted morphophonological contexts. One reason some speakers may have been hesitant to palatalize in our experiment may be due to task type. For example, Zuraw (2000) found that in a wug-type task, Tagalog speakers applied a nasal substitution process at low rates and failed to robustly show effects of voicing and place. However, Zuraw (2010) also found that in a later acceptability judgment task, such effects were more evident.

It is possible that the non-palatalizers in our study were similarly influenced by a task effect in this way - and that some participants might judge forms besides the ones they provided as acceptable. A key

${ }^{20}$ The Greater Dictionary of isiXhosa lists uku-gombonqa [úkú-góm ${ }^{\mathrm{m}} \grave{o ̀ n}^{\mathrm{n}}$ !à] and uku-gombonca [ùkù-gòm $\left.{ }^{\mathrm{bò}}{ }^{\mathrm{n}} \mid \mathrm{à}\right]$ as synonyms, meaning 'to hollow/scoop out'. The GDX does not list transparently extended forms like passives forms in most entries, but both of these items happen to have passive forms given. Interestingly, the former is shown with palatalization (uku-gonjonqa), and the latter without (uku-gombonca). This could be an indication that lexical choice matters in Xhosa - or that different editors of the dictionary had different intuitions, or speak different dialects, or any combination of these possibilities. 
difference between Zuraw's Tagalog case and the Xhosa case is that Xhosa speakers showed significant variation - some failed to apply palatalization at all, while others palatalized every token. If a task effect did impact the results presented here, it is on a per-speaker basis, rather than a blanket rule for Xhosa speakers. Another difference between the Tagalog and Xhosa cases is that the variation in Tagalog is on the level of lexical items, while the variation in Xhosa does not appear to be inherently linked to individual words, in that there are no reports of lexical exceptions to palatalization in passives (except those longdistance cases noted above).

\subsection{The place of phonetic naturalness in phonological theory}

A big-picture question encountered by our results is the role of phonetic naturalness in phonological theory. A considerable literature holds that phonological patterns are restricted by phonetic naturalness (see, e.g. Ohala 1990; Steriade 1997, 2008), or that phonological systems favor phonetically natural patterns due to biases in learning, or history, or both (e.g. Wilson 2003, 2006; Blevins 2004; Moreton 2008; Hayes et al. 2009; Culbertson et al. 2013; White 2013, 2017, among many others). Other approaches posit that phonetic knowledge is available to inform phonological patterns but does not necessarily restrict learning (Zuraw 2007; Kawahara 2008). This body of work contrasts with proposals that phonology is fundamentally disjoined from phonetics, and 'substance free' (Anderson 1981; Reiss 2016).

If considered as a transparent synchronic change, i.e., $/ \mathrm{m} / \rightarrow[\mathrm{n}]$, the labial palatalization found in Xhosa is not phonetically natural. If anything, co-articulation with [w] should reinforce a listener's perception of the labiality of a bilabial like $/ 6 /$ or $/ \mathrm{m} /$ (Ohala 1978, 1981), or perhaps make it sound more like a velar (Ohala \& Lorentz 1977: 584); [w] is not palatal-esque by nature. The change from bilabial to palatal is a change to a maximally dissimilar segment, skipping over numerous less-distant alternatives along the way. Recent artificial language experiments suggest that such patterns are difficult to learn and argue that speakers are inherently biased against them (White 2013, 2017; Hayes \& White 2015).

But what if we view the labial palatalization as a kind of dissimilation? This makes sense diachronically but does not make the alternation phonetically natural from a synchronic perspective. Consider Ohala's $(1978,1981)$ origin story for the labial palatalization pattern in (8), repeated here as (12).

$$
\text { s } / \mathrm{p}+\mathrm{jw} / \rightarrow \mathrm{pjw} \rightarrow \mathrm{p} \int \mathrm{w} \rightarrow \mathrm{t} \int \mathrm{w} \rightarrow / \mathrm{t} \int+\mathrm{w} /
$$

This account begs the question of whether a phonetically unnatural alternation might arise from the combination of discrete changes: it assumes that apparently phonetically unnatural changes are the results of opaque chains of changes, with each step along the way being phonetically sensible. While that analysis is appealing in that it reduces a seemingly unnatural pattern into phonetically natural steps, these steps are not evident from the surface realities of Xhosa phonology. Indeed, Ohala (1978: 379-380) explicitly notes that the synchronic situation does not provide a natural phonetic basis for the labial palatalization pattern in Tswana, and the same logic applies to its cognates in related languages like Xhosa.

It seems to us highly unlikely that speakers' synchronic grammars decompose the alternation in this way, and to this degree. $\mathrm{Cj}$ clusters are completely absent from the native lexicon in Xhosa, as are clusters like $\left[\mathrm{p} \int\right]$. The intermediate forms necessary to build the labial-palatal alternation out of phonetically natural sound changes are themselves phonotactically illicit. The only way the alternation can be seen as phonetically natural is if it is broken down into multiple steps, and these steps would have to be arrived at independently by Xhosa learners, with no evidence to speak of besides the absence of Bw clusters. Even if learners can generalize from the absence of local $\mathrm{Bw}$ clusters to the need for a general prohibition against labials co-occurring with [w], and even if we stipulate that phonetic naturalness is the basis for that similarity avoidance, it still does not make the entire chain phonetically natural. What works as a phonetically natural series of diachronic changes is not plausible as a phonetically natural synchronic mapping.

Given that synchronic labial palatalization is phonetically unnatural, the results presented in this paper are evidence that a phonetically unnatural pattern can nonetheless be learned and represented as synchronic 
phonology. The cross-speaker differences are intriguing, as they show that speakers do not all converge on a phonological representation of the pattern. Nonetheless, some speakers $d o$ treat labial palatalization as a regular, productive, phonological process. This entails that at least some types of phonetically unnatural patterns can be phonologically real. Consequently, we conclude that the space of phonological possibilities goes beyond what is phonetically natural.

Our results are still compatible with the view that phonetic naturalness might inform phonology in a non-deterministic way, for instance in the form of biases in learning. On this note, it is intriguing that so many of the participants in our sample exhibit behaviour consistent with palatalization being synchronic phonology of the familiar sort. We found more systematic palatalizers than non-palatalizers, which is perhaps surprising if phonology is indeed biased in favour of phonetic naturalness.

\section{Conclusion}

Two major conclusions are evident from this study.

The first is that different speakers of the same language, even those from the same speech community, can have significantly different phonological grammars. Some speakers in our sample have fully systematic palatalization in nonce words. Others do not palatalize in nonce words, and therefore appear to have learned the labial palatalization as an extra-phonological pattern, with palatalized forms stored directly in the lexicon. The same empirical pattern is phonological for some speakers, but lexicalized for others. The two groups therefore have considerably different phonologies. This finding is not novel - but is important to bear in mind for future studies, especially those that pool data across different speakers. We would also speculate that phonetically unnatural patterns are especially susceptible to this kind of variation, but this remains to be confirmed more broadly.

The second conclusion is that it is possible for at least some speakers to learn phonetically unnatural alternations as part of productive phonology. The labial-palatal alternations found in Xhosa are not of a phonetically sensible type unless decomposed into a chain of ordered steps. Decomposition of this sort is not justifiable from available evidence: none of the intermediate steps of the chain are evident in the synchronic phonology of Xhosa. Yet, we find that some speakers nevertheless exhibit labial palatalization systematically in nonce words, and thus seem to have it as part of their regular phonology. This entails that these speakers have learned a phonological grammar that produces phonetically unnatural patterns, which in turn entails that phonological patterns are not limited to those that make clear phonetic sense.

\section{Abbreviations}

In addition to abbreviations from the Leipzig Glossing Rules, the following are used in this article for language examples: INF infinitive; PASS passive; CAUS causative; FV final vowel morpheme. Abbreviations in the body text and/or footnotes include GDX The Greater Dictionary of isiXhosa (Tshabe et al. 2006); B for bilabial segments as a class; $\mathrm{J}$ for palatal segments as a class.

\section{Appendix}

List of stimuli items used in the experiment:

\begin{tabular}{|l|l|}
\hline Palatalization target $\mathbf{m} \rightarrow \mathbf{n}$ & Palatalization target ${ }^{\mathbf{m}} \mathbf{b} \rightarrow{ }^{\mathbf{n}} \widehat{\mathbf{d}} \mathbf{3}$ \\
iyahlama & iyasamba \\
iyashama & iyafamba \\
iyankama & iyakramba \\
iyaxama & iyagqamba \\
iyahama & iyachamba \\
iyafoma & iyavomba \\
\hline
\end{tabular}




\begin{tabular}{|l|l|}
\hline $\begin{array}{l}\text { iyakhoma } \\
\text { iyantloma } \\
\text { iyadloma } \\
\text { iyanoma }\end{array}$ & $\begin{array}{l}\text { iyakomba } \\
\text { iyadlomba } \\
\text { iyazomba } \\
\text { iyacomba }\end{array}$ \\
\hline$\underline{\text { Underlying } \mathbf{n} \mathbf{d}}$ & Underlying $\mathbf{n}$ \\
iyahlanja & iyashanya \\
iyathanja & iyabanya \\
iyaxhanja & iyathanya \\
iyavanja & iyakwanya \\
iyaphanja & iyagqanya \\
iyazonja & iyabhonya \\
iyagonja & iyatonya \\
iyabonja & iyangqonya \\
iyasonja & iyachonya \\
iyaqhonja & iyatshonya \\
\hline
\end{tabular}

\section{References}

Albright, Adam. 2010. Base-driven leveling in Yiddish verb paradigms. Natural Language \& Linguistic Theory 28(3). 475-537. https://doi.org/10.1007/s11049-010-9107-z.

Anderson, Stephen R. 1981. Why phonology isn't "natural". Linguistic Inquiry 12(4). 493-539.

Anttila, Arto. 1997. Deriving variation from grammar. In Frans Hinskens, Roeland van Hout \& Leo Wetzels (eds.), Variation, change and phonological theory, 35-68. Amsterdam: John Benjamins.

Baumbach, Erdmann J. 1987. Analytical Tsonga grammar. Pretoria: University of South Africa, Pretoria.

Bateman, Nicoleta. 2007. A crosslinguistic investigation of palatalization. La Jolla, CA: University of California, San Diego dissertation.

Bateman, Nicoleta. 2010. The change from labial to palatal as glide hardening. Linguistic Typology 14. 167-211. https://doi.org/10.1515/lity.2010.008.

Beckman, Jill N. 1993. Feature organization and the strong domain hypothesis in Zulu [labial] phonology. University of Massachusetts Occasional Papers 16. 1-26.

Bennett, Wm G. 2015. The phonology of consonants: Harmony, dissimilation, and correspondence. Cambridge: Cambridge University Press.

Berko, Jean. 1958. The child's learning of English morphology. Word 14. 150-177. https://doi.org/10.1080/00437956.1958.11659661.

Bhat, Darbhe N.S. 1978. A general study of palatalization. In Charles Ferguson, Joseph H. Greenberg \& Edith A. Moravcsik (eds.), Universals of human language, Vol. 2: Phonology, 47-92. Stanford: Stanford University Press.

Blevins, Juliette. 2004. Evolutionary phonology: The emergence of sound patterns. Cambridge: Cambridge University Press.

Boersma, Paul. 1997. How we learn variation, optionality, and probability. Proceedings of the Institute of Phonetic Sciences of the University of Amsterdam 21. 43-58.

Boersma, Paul \& Bruce Hayes. 2001. Empirical tests of the Gradual Learning Algorithm. Linguistic Inquiry 32. 45-86. https://doi.org/10.1162/002438901554586. 
Boersma, Paul \& Joe Pater. 2016. Convergence properties of a gradual learning algorithm for Harmonic Grammar. In John McCarthy \& Joe Pater (eds.), Harmonic Grammar and Harmonic Serialism, 389-434. Sheffield: Equinox

Cantrell, John V. 1946. Some aspects of Mpondo and its relation to Xhosa and Zulu. University of South Africa (UNISA) dissertation.

Chen, Su-I \& Gloria Malambe. 1998. Palatalization in Siswati: An Optimality Theoretic approach. In Ian Maddieson \& Thomas J. Hinnebusch (eds.), Language history and linguistic description in Africa, 137-146. Trenton, NJ: Africa World Press, Inc.

Claughton, John Sellick. 1992. The Tonology of Xhosa. Grahamstown, ZA: Rhodes University dissertation. http://hdl.handle.net/10962/d1002171.

Coetzee, Andries W. \& Rigardt Pretorius. 2010. Phonetically grounded phonology and sound change: The case of Tswana labial plosives. Journal of Phonetics 38. 404-421. https://doi.org/10.1016/j.wocn.2010.03.004.

Cole, Desmond T. 1955. An introduction to Tswana grammar. Cape Town: Longman.

Cook, Toni. 2013. Morphological and phonological structure in Zulu reduplication. Philadelphia: University of Pennsylvania dissertation.

Culbertson, Jennifer, Paul Smolensky \& Colin Wilson. 2013. Cognitive biases, linguistic universals, and constraint-based grammar learning. Topics in Cognitive Science 5(3). 392-424. https://doi.org/10.1111/tops. 12027.

de Lacy, Paul. 2009. Phonological evidence. In Steve Parker (ed.), Phonological argumentation: Essays on evidence and motivation, 43-78. Sheffield, UK: Equinox Publications.

Doke, Clement M. 1923. A dissertation on the phonetics of the Zulu language. Bulletin of the School of Oriental Studies 2(4). 685-729.

Doke, Clement M. 1954. The Southern Bantu languages. London: Oxford University Press.

Downing, Laura J. 2001. Liquid spirantization in Jita. Maililime: Malawian Journal of Linguistics 2. 1-27.

Eiselen, Roald \& Martin Puttkammer. 2014. Developing text resources for ten South African languages. Proceedings of the 9th International Conference on Language Resources and Evaluation. 3698-3703.

Gorecka, Alicja. 1989. The phonology of articulation. Cambridge, MA: Massachusetts Institute of Technology dissertation.

Goldwater, Sharon \& Mark Johnson. 2003. Learning OT constraint rankings using a maximum entropy model. Proceedings of the Workshop on Variation within Optimality Theory. 111-120.

Gouskova, Maria, Elizabeth Zsiga \& Tlale Boyer, One. 2011. Grounded constraints and the consonants of Setswana. Lingua 121(15). 2120-2152. https://doi.org/10.1016/j.lingua.2011.09.003.

Guzmán Naranjo, Matías. 2017. Analogy in formal grammar. Leipzig: University of Leipzig dissertation. http://ling.auf.net/lingbuzz/003689.

Hayes, Bruce. 2000. Gradient well-formedness in Optimality Theory. In Joost Dekkers, Frank Reinoud Hugo van der Leeuw, Jeroen Maarten van de Weijer (eds.), Optimality Theory: Phonology, syntax, and acquistion, 88-120. Oxford: Oxford University Press.

Hayes, Bruce, Pérter Siptár, Kie Zuraw \& Zsuzsa Londe. 2009. Natural and unnatural constraints in Hungarian vowel harmony. Language 85(4). 822-863. https://doi.org/10.1353/lan.0.0169 .

Hayes, Bruce \& James White. 2015. Saltation and the P-map. Phonology 32(2). 1-36. https://doi.org/10.1017/S0952675715000159.

Hayes, Bruce \& Colin Wilson. 2008. A maximum entropy model of phonotactics and phonotactic learning. Linguistic Inquiry 39(3). 379-440. https://doi.org/10.1162/ling.2008.39.3.379.

Herbert, Robert K. 1977. Morphophonological palatalization in southern Bantu: A reply to segmental fusion. Studies in African Linguistics 8(2). 41-63. 
Herbert, Robert K. 1990. Labial palatalization in Sotho and Nguni languages: Internal and external evidence. South African Journal of African Languages 10. 74-80. https://doi.org/10.1080/02572117.1990.10586836.

Hyman, Larry M. 2003. Sound change, misanalysis, and analogy in the Bantu causative. Journal of African Languages and Linguistics 24. 55-90. https://doi.org/10.1515/jall.2003.004.

Jessen, Michael \& Justus Roux. 2002. Voice quality differences associated with stops and clicks in Xhosa. Journal of Phonetics 30(1). 1-52. https://doi.org/10.1006/jpho.2001.0150.

Kawahara, Shigeto. 2008. Phonetic naturalness and unnaturalness in Japanese loanword phonology. Journal of East Asian Linguistics 17(4). 317-330. https://doi.org/10.1007/s10831-008-9030-z.

Khumalo, James Steven Mzilikatzi. 1987. An autosegmental account of Zulu phonology. Johannesburg: University of the Witwatersrand dissertation.

Khumalo, James Steven Mzilikatzi. 1988. Palatalization in Zulu. In A. C. Nkabinde (ed.), Anthology of Articles on African Linguistics and Literature: A Festschrift to C. L. S. Nyembezi, 71-99. Johannesburg: Lexicon Publishers.

Kochetov, Alexei. 2011. Palatalisation. In Colin Ewen, Elizabeth Hume, Marc van Oostendorp \& Keren Rice (eds.), Companion to phonology, 1666-1690. Oxford: Wiley Blackwell.

Kochetov, Alexei \& John Alderete. 2011. Patterns and scales of expressive palatalization: Experimental evidence from Japanese. Canadian Journal of Linguistics 56(3). 345-376.

Kuryłowicz, Jerzy. 1995. The nature of the so-called analogical processes. (Translated into English and with an introduction by Margaret E. Winters). Diachronica 12(1). 113-145.

Lee, Seunghun \& Clementinah Burheni. 2014. Repair strategies in labial dissimilation: Diminutive formations in Xitsonga. Stellenbosch Papers in Linguistics Plus 44(1). 89-103. https://doi.org/10.5842/44-0-642.

Louw, Jacobus A. 1975/76. Palatalization of bilabials in the passive, diminutive and locative in Xhosa and Tsonga. Afrika und Übersee 49(4). 241-278.

Malambe, Gloria Baby. 2006. Palatalization and other non-local effects in Southern Bantu languages. London: University College London dissertation.

Mańczak, Witold. 1980. Laws of analogy. Historical Morphology 17. 283-288.

McLaren, James. 1942. A Xhosa grammar. Cape Town: Longman, Green, and Co.

Moore-Cantwell, Claire. 2016. The representation of probabilistic phonological patterns: Neurological, behavioral, and computational evidence from the English stress system. Amherst, MA: University of Massachusetts dissertation.

Moreton, Elliott. 2008. Analytic bias and phonological typology. Phonology 25(1). 83-127. https://doi.org/10.1017/S0952675708001413.

Nagy, Naomi \& Bill Reynolds. 1997. Optimality Theory and variable word-final deletion in Faetar. Languge Variation and Change 9. 37-55. https://doi.org/10.1017/S0954394500001782.

Naidoo, Shamila. 2002. The palatalisation process in isiZulu revisited. South African Journal of African Languages 1. 59-69. https://doi.org/10.1080/02572117.2002.10587498.

Nemakhavhani, Daniel Phuluwani. 2002. Palatalization and labialization in Tshivenda: A linear and non-linear phonological analysis. Cape Town: Stellenbosch University Master's thesis.

Nyamende, Abner. 1994. Regional variation in Xhosa. Stellenbosch Papers in Linguistics Plus 26. 202-217. https://doi.org/10.5842/26-0-129.

O'Bryan, Margie. 1974. The role of analogy in non-derived formations in Zulu. Studies in the Linguistic Sciences 4(1). 144-178.

Ohala, John \& James Lorentz. 1977. The story of [w]: An exercise in the phonetic explanation for sound patterns. Proceedings of the Berkeley Linguistics Society (BLS) 3. 577-599. https://doi.org/10.3765/bls.v3i0.2264. 
Ohala, John. 1978. Southern Bantu vs. the world: The case of palatalization of labials. Proceedings of the Berkeley Linguistics Society (BLS) 4. 370-386. https://doi.org/10.3765/bls.v4i0.2218.

Ohala, John. 1981. The listener as a source of sound change. In Carrie S. Masek, Roberta A. Hendrick \& Mary Frances Miller (eds.), Papers from the Parasession on Language and Behavior, Chicago Linguistic Society (CLS), 178-203. Chicago: The University of Chicago.

Ohala, John. 1990. There is no interface between phonology and phonetics: A personal view. Journal of Phonetics 18. 153-171. https://doi.org/10.1016/S0095-4470(19)30399-7.

Podile, Kholisa. 2002. The dependency relations within Xhosa phonological processes. Johannesburg, ZA: University of South Africa Master's thesis.

Poulos, George \& Christian. T. Msimang. 1998. A linguistic analysis of Zulu. Cape Town: Via Afrika.

Reiss, Charles. 2017. Substance free phonology. In Stephen Hannahs \& Anna Bosch (eds.), The Routledge handbook of phonological theory, 435-452. London: Routledge.

Sibanda, Galen. 2004. Verbal phonology and morphology of Ndebele. Berkeley, CA: University of California dissertation.

Stahlke, Herbert F. W. 1976. Segment sequences and segmental fusion. Studies in African Linguistics 7. 41-63.

Spiegler, Sebastian, Andrew Van Der Spuy \& Peter A. Flach. 2010. Ukwabelana: An open-source morphological Zulu corpus. Proceedings of the 23rd International Conference on Computational Linguistics. 1020-1028.

https://github.com/LowResourceLanguages/bristol-mt-morphology.

Steriade, Donca. 1997. Phonetics in phonology: The case of laryngeal neutralization. Ms., Los Angeles, CA: University of California.

http://linguistics.ucla.edu/people/steriade/papers/PhoneticsInPhonology.pdf.

Steriade, Donca. 2008. The phonology of perceptibility effects: The P-map and its consequences for constraint organization. In Kristin Hanson, Sharon Inkelas \& René Kager (eds.), The nature of the word: Studies in honor of Paul Kiparsky, 151-180. Cambridge, MA: MIT Press.

Tshabe, Sonobo L., et al. 2006. The Greater Dictionary of IsiXhosa. Volumes 1-3, previously published in 1989, 2003. Alice, ZA: University of Fort Hare.

Van der Spuy, Andrew. 2014. Bilabial palatalisation in Zulu: A morphologically conditioned phenomenon. Stellenbosch Papers in Linguistics Plus 44. 71-87.

Wagner, Karl Heinz. 1969. 'Analogical change' reconsidered in the framework of generative phonology. Folia Linguistica 3(3-4). 228-241.

White, James. 2013. Bias in phonological learning: Evidence from saltation. Los Angeles: University of California dissertation.

White, James. 2017. Accounting for the learnability of saltation in phonological theory: A maximum entropy model with a P-map bias. Language 93(1). 1-36. https://doi.org/10.1353/lan.2017.0001.

Wilson, Colin. 2003. Experimental investigation of phonological naturalness. Proceedings of the $22^{\text {nd }}$ West Coast Conference on Formal Linguistics. 101-114.

Wilson, Colin. 2006. Learning phonology with substantive bias: An experimental and computational study of velar palatalization. Cognitive Science 30(5). 945-982. https://doi.org/10.1207/s15516709cog0000_89.

Zsiga, Elizabeth and Maria Gouskova. 2006. On the status of voiced obstruents in Tswana: Against *ND. Proceedings of NELS 36. 721-734.

Zuraw, Kie. 2007. The role of phonetic knowledge in phonological patterning: Corpus and survey evidence from Tagalog. Language 83(2). 277-316. https://doi.org/10.1353/lan.2007.0105. 
William G. Bennett

Department of English Language and Linguistics Artillery Road

Rhodes University.

Makhanda, 6140

South Africa

w.bennett@ru.ac.za
Aaron Braver

Department of English

Texas Tech University

P.O. Box 43091

Lubbock, TX 79409

USA

aaron.braver@ttu.edu 